\title{
Changes in Biomarkers of Exposure and Subjective Effects When Smokers Switch to Dual Use of Cigarettes and Either Snus or a Dissolvable Tobacco Product: A Summary of Three Clinical Studies *
}

\author{
by \\ Elaine K. Round ${ }^{1}$, Leanne R. Campbell ${ }^{1}$, Mitchell F. Stiles ${ }^{1}$, Michael Dixon ${ }^{2}$, Michael F. Borgerding ${ }^{1}$ \\ ${ }^{1}$ Research and Development Department, R.J. Reynolds Tobacco Company, Winston-Salem, N.C. 27102, USA \\ 2 Dixon Consultancy, Liphook Hampshire, $U K$
}

\section{SUMMARY}

A series of ambulatory clinical studies were conducted to evaluate changes in biomarkers of tobacco exposure and subjective product ratings when adult smokers switched to dual use of cigarettes with Camel Strips (Strips), Camel Sticks (Sticks), or Camel (SNUS). In all studies, subjects smoked ad libitum for one week (baseline). In incremental stages over three subsequent weeks, subjects were instructed to reduce cigarettes per day (CPD) by at least $75 \%$ and include use of one type of smokeless tobacco product (STP). Product use data was recorded by subjects daily, questionnaires were administered and smoked cigarette filters and used snus pouches were collected weekly, and 24-hour urine samples were collected at baseline and the end of dual use for measurement of biomarkers of tobacco exposure. In total, 100 subjects were enrolled, and 88 completed the studies. At the end of dual use, mean CPD reductions of approximately $60 \%$ were reported in all studies. Median levels of biomarkers of 4-(methylnitrosamino)-1-(3-pyridyl)-1-butanone (NNK) and acrolein either did not statistically significantly change or showed statistically significant decreases in all studies. Serum and urinary nicotine biomarkers did not significantly change. Twentyfive additional biomarkers were measured only in the SNUS study. Of those, 18 biomarkers statistically significantly decreased $12.4-35.7 \%$. No statistically significant increases in biomarker levels were observed in any of the studies. Decreases in some biomarkers confirmed that smoking reductions occurred but were less than the reported CPD reductions. Mouth-level exposure estimates suggest subjects did not significantly alter their puffing behavior to compensate for decreased CPD. Acceptability ratings of cigarettes decreased significantly during dual use, while ratings of Strips and SNUS increased, suggesting that the change in use behavior affected subjects' perceptions of the products. Results from these studies suggest that smokers who switch to dual use with either dissolvable tobacco or snus will likely not increase tobacco constituent exposure and may reduce exposure to some tobacco toxicants, especially those associated with combustion. [Beitr. Tabakforsch. Int. 26 (2015) 242-260]

\section{ZUSAMMENFASSUNG}

Es wurden mehrere ambulante klinische Studien durchgeführt, um die Veränderungen einerseits von Biomarkern für die Tabakexposition und andererseits von subjektiven Produktbewertungen bei der Umstellung von erwachsenen Rauchern auf die duale Anwendung von Zigaretten zusammen mit Camel Strips (Strips), Camel Sticks (Sticks) oder Camel SNUS (SNUS) zu untersuchen. In allen Studien rauchten die Probanden eine Woche lang ad libitum (Studienbeginn). In inkrementellen Schritten wurden die Studienteilnehmer in den darauffolgenden drei Wochen 
angewiesen, die Anzahl der Zigaretten pro Tag (cigarettes per day, CPD) um mindestens $75 \%$ zu reduzieren und zusätzlich ein rauchloses Tabakprodukt (smokeless tobacco product, STP) anzuwenden. Die Daten zur Produktanwendung wurden von den Teilnehmern täglich aufgezeichnet, Fragebögen wurden ausgegeben und die Filter der gerauchten Zigaretten und die gebrauchten Snus-Beutel wurden wöchentlich eingesammelt; zu Studienbeginn und am Ende der dualen Anwendung wurden außerdem 24-StundenUrinproben genommen, um Biomarker für die Tabakexposition zu bestimmen. Insgesamt nahmen 100 Probanden an den Studien teil. Hiervon schlossen 88 die Studien ab. Am Ende der dualen Anwendung wurden in allen Studien mittlere CPD-Reduktionen von etwa $60 \%$ berichtet. In allen Studien änderten sich die medianen Konzentrationen der Biomarker 4-(Methylnitrosamino)-1(3-pyridyl)-1-butanon (NNK) und Acrolein entweder nicht statistisch signifikant oder sie zeigten eine statistisch signifikante Abnahme. Nikotinbiomarker in Serum und Harn änderten sich nicht signifikant. 25 weitere Biomarker wurden nur in der SNUS-Studie bestimmt. Davon wurden bei 18 Biomarkern statistisch signifikante Reduktionen um $12,4-35,7 \%$ festgestellt. In keiner der Studien wurde ein statistisch signifikanter Anstieg eines Biomarkerwertes beobachtet. Durch die Abnahme mancher Biomarkerwerte konnte bestätigt werden, dass das Rauchen reduziert wurde, dennoch fiel die Abnahme geringer aus als die angegebene Reduktion der Anzahl Zigaretten pro Tag. Schätzungen der Exposition im Mundraum zufolge änderten die Probanden ihr Zugverhalten nicht signifikant, um die reduzierte Anzahl Zigaretten pro Tag auszugleichen. Die Akzeptanzbewertungen von Zigaretten nahmen während der dualen Anwendung signifikant ab, während sich die Bewertungen für Strips und SNUS verbesserten. Dies deutet darauf hin, dass die Änderung im Anwendungsverhalten die Wahrnehmung der Produkte seitens der Teilnehmer beeinflusst hat. Diese Studienergebnisse legen nahe, dass sich bei Rauchern, die auf eine duale Anwendung mit löslichem Tabak oder Snus umstellen, die Exposition gegenüber Tabakbestandteilen wahrscheinlich nicht erhöht und die Exposition gegenüber manchen Tabakschadstoffen, insbesondere denen, die mit der Verbrennung zusammenhängen, verringert werden kann. [Beitr. Tabakforsch. Int. 26 (2015) 242-260]

\section{RESUME}

Une série d'études cliniques ambulatoires furent menées en vue d'évaluer les variations des biomarqueurs d'exposition au tabac et de l'appréciation subjective des produits lorsque des fumeurs adultes passent à une consommation combinée composée de cigarettes associées à des bandelettes Camel (bandelettes), des bâtonnets Camel (bâtonnets) ou du tabac à sucer Camel (tabac à sucer). Dans toutes les études, les sujets furent invités à fumer ad libitum durant une semaine (période de référence). Ensuite, ils reçurent pour instruction de réduire progressivement, durant les trois semaines suivantes, leur consommation journalière de cigarettes (CJC) d'au-moins $75 \%$ et d'inclure la consommation d'un type de produit de tabac sans fumée (PTSF). Les données relatives à la consommation des produits furent consignées chaque jour par les sujets, des questionnaires furent remplis, les filtres des cigarettes fumées ainsi que les pochettes usagées de tabac à sucer furent récoltés chaque semaine et des échantillons d'urine furent prélevés toutes les 24 heures durant la période de référence ainsi qu'à la fin de la période de consommation combinée en vue de mesurer les biomarqueurs d'exposition au tabac. Au total, 100 sujets furent inclus et 88 menèrent les études à terme. A la fin de la période de consommation combinée, des réductions moyennes de la CJC avoisinant $60 \%$ furent observées dans toutes les études. Les valeurs médianes des biomarqueurs que sont la cétone de nitrosamine dérivée de la nicotine (4(méthylnitrosamino)-1-(3-pyridyl)-1-butanone) et l'acroléine ne présentèrent soit aucun changement statistiquement significatif soit des diminutions statistiquement significatives, toutes études confondues. Les biomarqueurs de la nicotine dans le sang et dans l'urine ne présentèrent aucune modification significative. Vingt-cinq biomarqueurs furent exclusivement mesurés lors de l'étude portant sur le tabac à sucer. Parmi ces 25 biomarqueurs, 18 affichèrent une diminution statistiquement significative de 12,4-35,7\%. Aucune augmentation statistiquement significative des valeurs des biomarqueurs ne fut observée, quelle que soit l'étude. Les diminutions de certains biomarqueurs confirmèrent certes que des réductions du tabagisme se produisaient bel et bien mais qu'elles s'avéraient inférieures aux réductions déclarées de CJC. Les estimations d'exposition des tissus buccaux laissent à penser que les sujets ne modifièrent pas significativement leur comportement d'aspiration des bouffées pour compenser le recul de la CJC. Les valeurs d'acceptabilité des cigarettes chutèrent de façon significative durant la période de consommation combinée tandis que l'appréciation des bandelettes et du tabac à sucer s'améliora, laissant à penser que la modification du comportement de consommation avait altéré les perceptions des produits chez les sujets. Les résultats de ces études suggèrent que les fumeurs qui basculent vers une consommation combinée associant la cigarette soit à du tabac soluble soit à du tabac à sucer n'augmenteront, selon toute attente, pas leur exposition aux constituants de tabac et sont susceptibles de réduire leur exposition à certaines substances toxiques du tabac, tout particulièrement aux substances associées à la combustion. [Beitr. Tabakforsch. Int. 26 (2015) 242-260]

\section{ABBREVIATIONS}

$\begin{array}{ll}\text { AAMA } & N \text {-acetyl-S-(3-amino-3-oxypropyl)-cysteine } \\ \text { 2-AN } & \text { 2-aminonaphthalene } \\ \text { 3-ABP } & \text { 3-aminobiphenyl } \\ \text { 4-ABP } & \text { 4-aminobiphenyl } \\ \text { B }[a] \text { P } & \text { benzo[a]pyrene } \\ \text { CEMA } & \text { 2-cyanoethylmercapturic acid } \\ \text { COHb } & \text { carboxyhemoglobin } \\ \text { CPD } & \text { cigarettes per day } \\ \text { DTP } & \text { dissolvable tobacco product } \\ \text { ECO } & \text { expired carbon monoxide } \\ \text { ESI } & \text { electrospray ionization } \\ \text { GAMA } & N \text {-acetyl- } S \text {-(3-amino-2-hydroxy-3-oxopropyl)- } \\ & \text { cysteine } \\ \text { GC } & \text { gas chromatography }\end{array}$


HEMA 2-hydroxyethylmercapturic acid

HILIC hydrophilic interaction liquid chromatography

HMPMA 3-hydroxy-1-methylpropylmercapturic acid

HPLC high performance liquid chromatography

3-HPMA 3-hydroxypropylmercapturic acid

LC liquid chromatography

LOQ limit of quantification

MHBMA monohydroxybutyl-mercapturic acids, 1-hydroxy-2-( $N$-acetylcysteinyl)-3-butene and 1-( $N$-acetylcysteinyl)-2-hydroxy-3-butene

MLE mouth level exposure

MNWS Minnesota Nicotine Withdrawal Scale

MS mass spectrometry

NAB $\quad N^{\prime}$-nitrosoanabasine

NAT $\quad N^{\prime}$-nitrosoanatabine

NicEq nicotine equivalents

NNK 4-(methylnitrosamino)-1-(3-pyridyl)-1-butanone

NNN $\quad N$ '-nitrosonornicotine

NNAL 4-(methylnitrosamino)-1-(3-pyridyl)-1-butanol

SPE solid phase extraction

SPMA $S$-phenylmercapturic acid

STP smokeless tobacco product

TSNA tobacco-specific nitrosamine

UB usual brand

\section{INTRODUCTION}

With the passage of the Family Smoking Prevention and Tobacco Control Act (FSPTCA) in 2009, the US Food and Drug Administration (FDA) was provided with certain authority to regulate tobacco products to protect public health. This authority currently extends to traditional tobacco products such as cigarettes and moist snuff as well as to smokeless tobacco products that are newer to the US consumer market such as snus and dissolvable tobacco products (DTPs). A draft deeming regulation, once finalized, will bring other products that meet the statutory definition of "tobacco product," such as electronic cigarettes, under regulatory authority as well (1).

Cigarette smoking is a primary public health concern. It is a leading cause of preventable death in the United States and significantly increases the risk of developing serious disease and adverse health conditions (2). The risk for serious diseases is significantly affected by the type of tobacco product used and the frequency, duration, and manner of its use. On a continuum of risk of tobacco and nicotine-containing products, cigarettes fall on one end of the continuum, primarily due to exposure to constituents formed during the combustion process. Nicotine replacement therapies fall on the other end of the continuum and are associated with the lowest risk to health by the consumer. In the middle, but closer to nicotine replacement therapies are smokeless tobacco products that contain lower levels of harmful or potentially harmful constituents, such as snus and dissolvable tobacco products.

In order to reduce the harm associated with tobacco use, the public health community consistently supports advising current smokers to quit smoking and never smokers not to start. However, for those smokers who are unwilling or unable to quit, some in the public health community have suggested that switching to a product lower on the contin- uum of risk would decrease exposure to the combustion products of tobacco and may reduce the risk of developing adverse health conditions from tobacco product use (3). For example, scientific evidence from the adoption of snus in Sweden clearly shows that smokers who completely switch from cigarettes to a non-combustible form of tobacco experience health benefits that include lower relative risks for major smoking-related diseases, including lung cancer (4-6). A scenario with a complete switch away from cigarettes would result in the greatest reduction in exposure. However, other possible scenarios for use exist, including the possibility that a smoker may choose to decrease cigarette consumption by adopting use of an additional tobacco product. These possibilities raise questions about the possible health effects of concurrent use of more than one tobacco product type. For example, the scenario of concurrent use of cigarettes with dissolvable products was evaluated for possible effects on public health by the scientific advisory committee to the FDA Center for Tobacco Products. Their report published in March 2012 (7) evaluated three potential patterns of tobacco product use, including a "mixed pattern that involved multiple products, including DTPS". Among the recommendations for future testing, the Tobacco Products Scientific Advisory Committee (TPSAC) stated that "doses of key components delivered to users should be assessed with an appropriate suite of biomarkers".

Several recent studies have assessed changes in the levels of biomarkers of tobacco exposure in smokers switched to dual use with snus or a DTP while in clinical confinement. One study assessed changes in biomarkers when smokers reduced daily cigarette consumption by around $50 \%$ and were allowed dual use of cigarettes and Marlboro Snus for eight days (8). The authors reported that the dual use of cigarettes and snus resulted in proportionate reductions in the levels of a number of biomarkers of exposure relative to $\mathrm{CPD}$ reductions.

A second study included a group of smokers who were switched for five days to a work day-like scenario that limited the times of day smoking was permitted but did not restrict the number of cigarettes (9). During the nonsmoking period (and throughout the day) the smokers were also permitted use of Camel Orbs. Results of the switch showed a small CPD decrease of approximately $11 \%$ with low use of Orbs. Biomarkers of tobacco exposure showed no significant increases, and significant decreases of 3-28\% were observed for some biomarkers.

A third study included a group of smokers who were switched to reduce CPD by $60 \%$ and allowed use of Camel SNUS for five days while in clinical confinement (10). Most biomarkers decreased significantly by approximately $20-50 \%$, and only two biomarkers did not change significantly. Snus use averaged 3.2 pouches per day.

The studies presented in this paper evaluated smokers who changed product use in their natural environments to reduce cigarettes per day while also using either dissolvable tobacco strips (Strips), dissolvable tobacco sticks (Sticks), or Camel SNUS (SNUS) for three weeks. Goals for cigarette reduction were set for each week and smokeless tobacco products were provided to the volunteers for use. Subjects reported to the study clinic once a week for evaluation. This paper reports changes in product use 
Table 1. Product characterization ( $n=3$ for each analysis).

\begin{tabular}{|c|c|c|c|c|c|c|c|c|c|c|}
\hline \multirow{2}{*}{$\begin{array}{l}\text { Type of analysis } \\
\text { Nicotine (mg/unit) }\end{array}$} & \multicolumn{3}{|c|}{$\begin{array}{c}\text { Strips } \\
\text { mean } \pm \text { SD }\end{array}$} & \multicolumn{2}{|c|}{$\begin{array}{c}\text { Sticks } \\
\text { mean } \pm \text { SD }\end{array}$} & \multicolumn{2}{|c|}{$\begin{array}{l}\text { SNUS Frost } \\
\text { mean } \pm \text { SD }\end{array}$} & \multicolumn{3}{|c|}{$\begin{array}{c}\text { SNUS Mellow } \\
\text { mean } \pm \text { SD }\end{array}$} \\
\hline & 0.34 & \pm & 0.06 & 1.39 & \pm 0.28 & 6.72 & \pm 0.00 & 6.36 & \pm & 0.00 \\
\hline NNN ( $\mu \mathrm{g} /$ unit) & 0.081 & \pm & 0.004 & 0.235 & \pm 0.010 & 0.732 & \pm 0.044 & 0.784 & \pm & 0.011 \\
\hline NNK ( $\mu \mathrm{g} / \mathrm{unit})$ & 0.022 & \pm & 0.001 & 0.146 & \pm 0.005 & 0.220 & \pm 0.002 & 0.241 & \pm & 0.011 \\
\hline $\mathrm{B}[\mathrm{a}] \mathrm{P}$ (ng/unit) & 0.099 & \pm & 0.016 & 0.669 & \pm 0.122 & 1.416 & \pm 0.042 & 1.260 & \pm & 0.228 \\
\hline $\mathrm{pH}$ & 7.51 & \pm & 0.01 & 7.53 & \pm 0.01 & 7.72 & \pm 0.01 & 7.75 & \pm & 0.01 \\
\hline Moisture (\%) & 12.2 & \pm & 0.1 & 4.8 & \pm 0.1 & 31.7 & \pm 0.2 & 32.0 & \pm & 0.1 \\
\hline
\end{tabular}

behaviors, subjective effects, and biomarkers of tobacco exposure from baseline smoking through the last day of dual use. These studies provide the first data of this type with smokers who temporarily switch to dual use of cigarettes and either snus or dissolvable tobacco in their natural environments.

\section{METHODS}

\section{Subjects}

Subjects in all studies were included if they were 21-55 years of age, in generally good health and free of clinically significant oral lesions as determined by the study physician. In addition, subjects reported smoking cigarettes as their primary form of tobacco use and reported smoking at least seven cigarettes per day of a usual brand (UB) with a Cambridge Filter Method (CFM) "tar" yield of 8.0-14.0 mg per cigarette when machine smoked according to the following regime: $35 \mathrm{~mL}$ puff volume, $2 \mathrm{sec}$ puff duration, one puff per min. ${ }^{1}$ Subjects were excluded if they were pregnant, breastfeeding, or planning to become pregnant during the study or if they reported delaying a decision to quit smoking to participate. Subjects were recruited from the Winston-Salem, NC area. Each study proposal was submitted to and approved by the R.J. Reynolds Tobacco Company's Research and Development Human Research Review Committee before study initiation. All subjects participated in an orientation session to explain study requirements. Written informed consent was provided by all subjects before study procedures were initiated. Subject eligibility was determined during a single screening visit for each study.

\footnotetext{
1 At the time this study was conducted, this "tar" range of cigarette was considered to be Full Flavor Low Tar and referred to as such in the study. Use of the term "low" and other similar descriptors was subsequently banned by the Family Smoking Prevention and Tobacco Control Act. The CFM was previously referred to as the Federal Trade Commission (FTC) method ("FTC Rescinds Guidance from 1966 on Statements Concerning Tar and Nicotine Yields," FTC https://www.ftc.gov/news-events/pressreleases/2008/11/ftc-rescinds-guidance-1966-statements-concerning-tar -nicotine, accessed 24 June 2015). Prior to its rescission in 2008 (ibid.), the method was prescribed by the FTC as the standardized method for reporting cigarette "tar" and nicotine values (Fed. Reg. 32 (147): 11178 (1967)).
}

\section{Test products}

Subjects provided their own purchased UB cigarettes for use throughout study participation. The dissolvable tobacco products (Strips and Sticks) and SNUS were provided to subjects for use at no cost to them during the dual-use phase. The STP provided for use was dependent on the study design.

Strips are approximately $22 \mathrm{~mm} \times 32 \mathrm{~mm}$ thin films weighing approximately $127 \mathrm{mg}$ and composed of milled tobacco and food-grade materials. Strips completely dissolve in the mouth within two to three minutes after placement.

Sticks are also composed of milled tobacco and food-grade materials and are similar in size and shape to a thick toothpick weighing approximately $582 \mathrm{mg}$ and approximately $76 \mathrm{~mm}$ in length. An entire Stick completely dissolves in the mouth over a period of approximately $30 \mathrm{~min}$ and may be used whole or broken into pieces. Both Strips and Sticks were introduced into a three-city lead market in 2009 as Camel Strips and Camel Sticks. The products were tested unbranded in these studies.

SNUS is a pouched, heat-treated moist snuff product designed to be used without the need to spit. Two varieties of 600-mg pouches, 'Frost' and 'Mellow,' were used in the study and were similar in composition. SNUS was distributed to subjects in tins branded as Camel SNUS.

Moisture content, $\mathrm{pH}$, and the levels of nicotine, $N$ '-nitrosonornicotine (NNN), 4-(methylnitrosamino)-1-(3-pyridyl)-1butanone $(\mathrm{NNK})$, and benzo $[a]$ pyrene $(\mathrm{B}[a] \mathrm{P})$ for the three products are shown in Table 1. Product analyses were performed by Labstat International ULC (Kitchener, Ontario, Canada). Before analysis, all products were ground and sieved to ensure $\leq 4 \mathrm{~mm}$ particle size. $\mathrm{pH}$ was determined using Health Canada method T-310, Determination of Whole Tobacco $\mathrm{pH}$ (11). Moisture was determined using Health Canada method AOAC 966.02, Loss on Drying (Moisture) in Tobacco, Gravimetric Method (12). Nicotine was determined using the Centers for Disease Control method, Determination of Nicotine in Tobacco Products (13) with one modification. The sample size of the Strips and Sticks analyses was doubled from $1 \mathrm{~g}$ to $2 \mathrm{~g}$ in order to enhance the limit of quantification. Tobacco-specific nitrosamines (TSNAs) were determined using LC-MS/MS with positive electrospray ionization (ESI) (14-16). B[a]P was determined using purification stages consisting of liquid/liquid partitioning and solid phase extraction (SPE) with a $\mathrm{NH}_{2} /$ silica gel two phases cartridge prior to GC/MS analysis (17-19). The levels of these constituents were below the GothiaTek ${ }^{\circledR}$ limits (20) for all three products. 


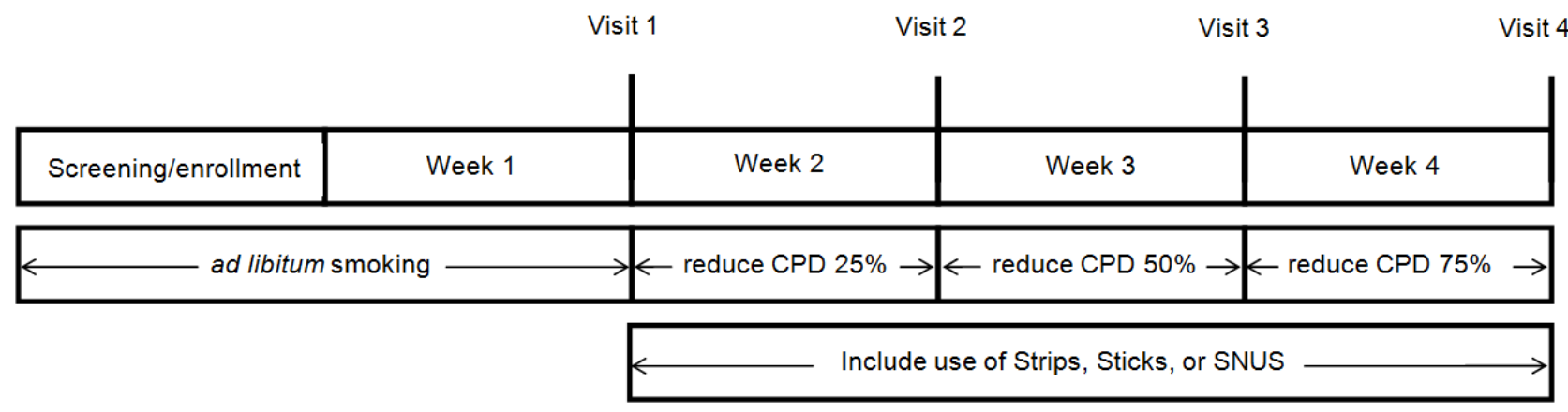

Figure 1. Study design. $\mathrm{CPD}=$ cigarettes per day, indicated percent reductions in CPD for Weeks $2-4$ are relative to subject-reported Week 1 CPD.

\section{Study design and procedures}

These investigations were conducted as three separate studies with three different groups of smokers. Each study involved a three-week transition from exclusive cigarette smoking to both reduced smoking and unrestricted use of Strips, Sticks, or SNUS. Subject participation occurred during September 2008 (Strips), October/November 2008 (Sticks) and May/June 2009 (SNUS). Some procedures in the SNUS study were modified slightly based on knowledge gained from the earlier Strips and Sticks studies.

Within each study, a staged reduction in cigarette consumption occurred. In the first week of participation, subjects smoked as usual and recorded the number of cigarettes smoked each day on a product use log. The average daily cigarette consumption for each subject was used to determine individual, incremental CPD reduction goals for the second, third, and fourth weeks of the study. Subjects were instructed to reduce smoking by $25 \%$ during Week 2, 50\% during Week 3, and 75\% during Week 4, and use either Strips, Sticks, or SNUS, according to the study. A schematic of the study design is shown in Figure 1. Subjects were required to abstain from all tobacco product use for at least $30 \mathrm{~min}$ before the start time of each study visit. Study visits were conducted between 12 p.m. and 4:30 p.m.

Week 1 and Visit 1 - During the week prior to Visit 1 (Week 1), subjects smoked their UB cigarettes without restriction and recorded the number of cigarettes smoked per day. The day before Visit 1, subjects collected a 24-h urine sample and all their spent cigarette butts in study-provided kits. At Visit 1, subjects returned completed product use logs, cigarette butt collection kits, and 24-h urine samples. In clinic, subjects in all studies provided and smoked one UB cigarette. In the Strips and Sticks studies, subjects used either one Strip or one-third of a Stick $30 \mathrm{~min}$ after the start of smoking their UB cigarette. Blood samples for determination of nicotine and cotinine concentrations were collected at designated time points before, during, and after use of each product (data not shown). Expired carbon monoxide (ECO) levels and carboxyhemoglobin $(\mathrm{COHb})$ saturation were measured before the start of smoking in the SNUS study only. Subjects in all studies completed questionnaires to assess tobacco abstinence symptoms and to evaluate the study products used during the visit. At the end of Visit 1, subjects were given their individual CPD reduction targets for Week 2 and were provided with supplies of Strips, Sticks, or SNUS (according to the study).
Week 2 and Visit 2 - Subjects were instructed to reduce their daily cigarette consumption by $25 \%$ during Week 2 and incorporate Strips, Sticks, or SNUS into their daily tobacco use routines. Subjects recorded the numbers of UB cigarettes and STPs used each day during Week 2 and collected all butts from the cigarettes smoked the day prior to Visit 2. The completed product use logs and cigarette butts were returned at Visit 2. During the visit, each subject used one Strip, Stick, or SNUS pouch and completed questionnaires after product use. At the end of Visit 2, subjects were given their individual CPD reduction targets for Week 3 and were dispensed supplies of Strips, Sticks or SNUS.

Week 3 and Visit 3 - The procedures for Week 3 and Visit 3 were the same as those for Week 2 and Visit 2 except that subjects were instructed to reduce their daily cigarette consumption by $50 \%$ relative to individual average Week 1 CPD.

Week 4 and Visit 4 - During Week 4, subjects were instructed to further reduce their daily cigarette consumption by $75 \%$ relative to Week 1 . Subjects collected cigarette butts and 24-h urine samples at home the day before Visit 4. The procedures at Visit 4 were similar to those of Visit 1 except for product use. Subjects did not smoke and used only a Strip, Stick, or SNUS pouch, depending on the study. Blood samples were collected at designated time points before, during, and after use of the relevant smokeless product for measurement of nicotine and cotinine concentrations (data not shown). In the SNUS study only, ECO was measured in exhaled breath before product use, and blood was collected before product use for determination of $\mathrm{COHb}$ saturation.

\section{Mouth-level exposures from cigarette smoking}

Mouth-level exposures (MLEs) to "tar" and nicotine from the cigarettes smoked by subjects were obtained by the part-filter analysis technique $(21,22)$. The estimation of MLE relies on using the relationships between the mainstream smoke yields of "tar" and nicotine and the amounts of "tar" and nicotine retained within the filter tips of the cigarettes after smoking.

Subjects were given collection kits and were instructed to collect the filters from all cigarettes smoked the day before Visits 1 through 4 . Upon completion of smoking a ciga- 
rette, each butt (filter plus residual tobacco) was placed into a separate plastic vial. The vial was sealed using a screw cap to extinguish the cigarette while maintaining the integrity of the filter. The subjects returned the kits containing collected butts at each test visit. Returned kits were stored at $-20{ }^{\circ} \mathrm{C}$ until processing. After equilibrating to room temperature to facilitate processing, butts were removed from the vials, and a $10-\mathrm{mm}$ section was cut from the mouth end of each filter. Filter tip sections were batched per subject and frozen at $-70^{\circ} \mathrm{C}$ or below before being shipped to Arista Laboratories (Richmond, VA, USA) for analysis. The cut tips were grouped into batches of four to six and analyzed to estimate the "tar" and nicotine MLE of the smokers.

NNK MLEs from cigarette smoking were estimated for subjects for whom brand style-specific NNK-to-nicotinemainstream-smoke correlations were available (Bodnar, personal communication). Linear regression equations for mainstream smoke NNK and nicotine yields were established using yield data obtained from a range of machine smoking regimes for approximately half of the cigarette brand styles used in the study. Data were available for the UBs of 16 subjects in the Strips study, 12 subjects in the Sticks study, and 15 subjects in the SNUS study. NNK MLEs were derived using the nicotine MLEs for each subject and the regression coefficients obtained from the relationship between mainstream smoke NNK and nicotine yields obtained from the calibration smoking procedures.

The machine smoking parameters and smoking machine conditions used for mainstream smoke analysis were those described in International Organization for Standardization standard ISO 3308, Fourth Edition 2000-04-15, Routine Analytical Cigarette-Smoking Machine - Definitions and Standard Conditions, 2000 (E) (24).

NNK mainstream smoke yields were determined by the Health Canada Method T-111 (25). Nicotine mainstream smoke yields were determined by the Health Canada Method T-115 (26). Analyses were performed by Labstat ${ }^{\mathbb{R}}$ International ULC (Kitchener, Ontario, Canada).

MLE to nicotine and NNK from cigarettes for Week 1 and Week 4 was calculated by multiplying a subject's constituent-specific average MLE per cigarette by the subjectreported number of cigarettes smoked on Day 7 of the respective week.

\section{Mouth-level exposures from use of STPS}

Because Strips and Sticks dissolve completely in the mouth, daily MLEs from Strips or Sticks use for Week 4 were estimated by multiplying the number of Strips or Sticks used on Day 7 of that week by the average constituent level found in a Strip or Stick (Table 1). Subjects in the SNUS study were asked to collect all used snus pouches during study Weeks 3 and 4. Subjects were provided with one amber glass jar for each day of collection and started use of a new jar each day. Subjects were asked to place all used pouches into the jar. At the end of each day, subjects placed the jar into a home freezer until the jars were returned at the subject's next visit.

The used pouches and lot-matched unused pouches were sent to Labstat ${ }^{\mathbb{B}}$ International ULC for analysis of the levels of nicotine, nornicotine, anatabine, $\mathrm{B}[a] \mathrm{P}, \mathrm{NNK}, \mathrm{NNN}, N^{\prime}$ - nitrosoanabasine (NAB), and $N$ '-nitrosoanatabine (NAT), and trace metals (data not shown). The methods used for constituent determination are described in CARAWAY and CHEN (23). The quantities of constituents remaining in the used pouches obtained from each subject were subtracted from the average quantity present in lot-matched unused pouches to estimate the amounts of each constituent removed during use. Daily MLEs from SNUS use for Week 4 were estimated for each subject by multiplying the average amounts of constituents extracted per pouch by the subject-reported number of pouches used on Day 7 of that week.

\section{Exhaled carbon monoxide measurement}

A Bedfont Micro 4 Smokerlyzer ${ }^{\mathbb{B}}$ unit (Bedfont, Harrietsham, Kent, UK) was used to determine ECO levels in the SNUS study. Subjects were instructed to inhale deeply, hold their breath for 15 seconds, and then exhale slowly and completely through a disposable mouthpiece attached to the instrument. Readings were obtained in parts per million (ppm).

\section{Carboxyhemoglobin saturation}

In the SNUS study only, blood samples were obtained just before product use at Visits 1 through 4 for determination of carboxyhemoglobin saturation. An Instrumentation Laboratories IL-682 CO-Oximeter (Instrumentation Laboratories, Bedford, MA, USA) was used to measure the $\mathrm{COHb}$ levels as a percentage of total hemoglobin $(\% \mathrm{COHb})$ from whole blood samples collected in tubes containing $\mathrm{K}_{2}$ EDTA. COHb saturation was determined at the study site within an hour of sample collection.

\section{Serum nicotine and cotinine measurements}

Blood samples collected at designated time points before, during, and after product use at Visits 1 and 4 were allowed to clot at room temperature for at least $30 \mathrm{~min}$ and were processed the day of collection. Tubes containing clotted blood were spun at $3000 \mathrm{rpm}$ for $20 \mathrm{~min}$ at $8^{\circ} \mathrm{C}$. Serum was aliquotted into cryovials and stored at approximately $-70{ }^{\circ} \mathrm{C}$. Samples were shipped frozen to ABF Laboratories (Munich, Germany) for nicotine and cotinine measurements.

Serum nicotine and cotinine concentrations were determined by liquid chromatography, tandem mass spectrometry (LC-MS/MS) following protein precipitation with methanol and centrifugation, according to MEGER et al. (27). A modification was made in that $10 \mu \mathrm{L}$ of the supernatant were injected into the LC-MS/MS system. Results were reported in $\mathrm{ng} / \mathrm{mL}$. Only baseline serum cotinine results are reported here.

\section{Urinary biomarkers of exposure}

Subjects started collection of 24-h urine samples after the first void the day before Visits 1 and 4 and ended with the first void the following morning. Urine samples were kept cold throughout collection using ice packs and coolers provided to subjects and were returned the afternoon 
following completion at the respective test visit. The volume of each sample was measured, and the samples were stirred at room temperature for $10 \mathrm{~min}$, aliquotted, and frozen at approximately $-20{ }^{\circ} \mathrm{C}$. Samples were shipped frozen to ABF GmbH (Munich, Germany) for determination of all specified urinary biomarkers. Total daily excretion yields for each biomarker were determined by multiplying the observed concentration by the total urine volume for each 24-h collection. Urine collections were considered complete if total 24-h creatinine excretion was greater than the lower limit of gender-specific adult reference ranges: $800 \mathrm{mg} /$ day for males and $600 \mathrm{mg} /$ day for females (28).

Selected urinary biomarkers were measured in the Strips and Sticks studies. These included nicotine equivalents (NicEq), 3-hydroxypropylmercapturic acid (3-HPMA, a metabolite of acrolein), and free plus $\mathrm{N}$-glucuronidated (total) 4-(methylnitrosamino)-1-(3-pyridyl)-1-butanol (NNAL-T), a metabolite of the TSNA NNK). In addition, several additional biomarkers described below were measured in the SNUS study.

\section{Nicotine}

The concentrations of nicotine and nine metabolites were determined by LC-MS/MS according to MEGER et al. (27) with major modifications. The most significant change from the original method, which measured nicotine plus eight metabolites, was that the analysis was performed using two separate methods: (i) nicotine plus five metabolites (cotinine, trans-3'-hydroxycotinine, nicotine-glucuronide, cotinine- $N$-glucuronide, and trans-3'-hydroxycotinine$\mathrm{N}, \mathrm{O}$-glucuronide) and (ii) four metabolites including norcompounds and $\mathrm{N}$-oxides (nornicotine, norcotinine, nicotine- $N$-oxide, and cotinine- $N$-oxide). For analysis of nicotine plus five metabolites, the only modification from the cited method was in the sample work-up, which included protein precipitation with methanol and centrifugation. Multiple modifications for analysis of the four metabolites including nor-compounds and $\mathrm{N}$-oxides (ii) included the following: sample processing involved only centrifugation; the injection volume was increased to $10 \mu \mathrm{L}$; the analytical column was a reversed phase (RP) C18; chromatographic separation utilized a mobile phase gradient; and positive ESI was used. The limit of quantification (LOQ) was decreased about three-fold. To determine NicEq, the daily mass of each metabolite excreted was converted to an equivalent mass of nicotine using a metabolitespecific molar ratio. Converted masses of each metabolite were summed to obtain NicEq (mg nicotine/24-hr).

\section{Tobacco-specific nitrosamines}

Total (sum of the free base and glucuronide) TSNAs were determined by LC-MS/MS according to KAVVADIAS et al. (29). NNK exposure was evaluated in all three studies by measuring urinary levels of NNAL-T. Total NNN (NNN$\mathrm{T}$ ), total NAB (NAB-T), and total NAT (NAT-T) were evaluated in the SNUS study only.

\section{Acrylamide and acrolein}

Determinations of $\mathrm{N}$-acetyl-S-(3-amino-3-oxypropyl)cysteine (AAMA) and $N$-acetyl- $S$-(3-amino-2-hydroxy-3oxopropyl)-cysteine (GAMA), two metabolites of acrylamide, were performed by LC-MS/MS according to URBAN et al. (30) with major modifications including the addition of 3-HPMA (a metabolite of acrolein) measurement. Modifications, associated with the measurement of HPMA, included the following: addition of the labelled internal standard (IS) ${ }^{15} \mathrm{~N},{ }^{13} \mathrm{C}_{3}$-HPMA; a change in chromatographic separation to hydrophilic interaction liquid chromatography (HILIC) using isocratic elution $(5 \mathrm{mM}$ aqueous ammonium acetate $/ 5 \mathrm{mM}$ ammonium acetate in acetonitrile [1:10]); and multiple reaction monitoring (MRM) ion transitions $(\mathrm{m} / \mathrm{z})$ for HPMA $(220 \rightarrow 89)$ and HPMA IS $(224 \rightarrow 89)$. The LOQ for AAMA decreased to $4.1 \mathrm{ng} / \mathrm{mL}$, while the LOQ for GAMA increased to $1.0 \mathrm{ng} / \mathrm{mL}$. 3-HPMA was determined in all three studies while AAMA and GAMA were determined in the SNUS study only.

\section{Aromatic amines}

Concentrations of the aromatic amines $o$-toluidine, 4-aminobiphenyl (4-ABP), 3-aminobiphenyl (3-ABP), and 2-aminonaphthalene (2-AN) were determined by gas chromatography-mass spectrometry (GC-MS) according to RIEDEL et al. (31). Aromatic amines were determined in the SNUS study only.

\section{Polycyclic aromatic hydrocarbons}

Concentrations of phenolic metabolites of polycyclic aromatic hydrocarbons (OH-PAHs) naphthalene, fluorene, phenanthrene, and pyrene were determined by GC-MS/MS according to RAMSAUER et al. (32) with major modifications. Modifications included the following: the cited method describes an LC-MS/MS assay compared with the GC-MS/MS assay employed here; the volume of urine used was increased to $10 \mathrm{~mL} ; 10 \mathrm{~mL}$ of $\mathrm{n}$-hexane/acetonitrile (100:0.7) was used for elution from C18 solid phase extraction (SPE) cartridges, followed by derivatization with pentafluoropropionic acid anhydride; and all OH-PAHs were chromatographically separated. The LOQs remained comparable. Metabolites assayed included: 1- and 2-OHnaphthalene, 2-OH-fluorene, 1-, 2-, 3-, and 9-OH-phenanthrene, and 1-OH-pyrene. Hydroxylated PAHs were determined in the SNUS study only.

Other vapor phase constituents (benzene, crotonaldehyde, 1,3-butadiene, acrylonitrile, ethylene oxide, hydrogen cyanide)

$S$-phenylmercapturic acid (SPMA), a metabolite of benzene, was measured by HPLC-MS/MS with modifications made to a method by PACI et al. (33). Modification of the method included hydrochloric acid treatment of the urine samples to convert the precursor of SPMA to SPMA (34). Determination of 3-hydroxy-1-methylpropylmercapturic acid (HMPMA), a metabolite of crotonaldehyde, was performed by HPLC-MS/MS according to SCHERER et al. (35). 
Concentrations of 1-hydroxy-2-( $N$-acetylcysteinyl)-3-butene and 1-( $N$-acetylcysteinyl)-2-hydroxy-3-butene [collectively called monohydroxybutyl-mercapturic acids (MHBMA)], two metabolites of 1,3-butadiene, were determined by LCMS/MS according to URBAN et al. (36) with modifications. Modifications included the following: a reduction in the volume of urine used to $100 \mu \mathrm{L}$; elimination of the SPE step; a change in chromatographic separation to HILIC; and a transition in ionization mode to negative ESI. The LOQ for MHBMA was improved to $0.1 \mathrm{ng} / \mathrm{mL}$.

Concentrations of 2-hydroxyethylmercapturic acid (HEMA), a metabolite of ethylene oxide, and 2-cyanoethylmercapturic acid (CEMA), a metabolite of acrylonitrile, were determined by LC-MS/MS according to SCHERER et al. (37).

Thiocyanate, a metabolite of hydrogen cyanide, was determined by GC-MS according to TORAÑO and VAN KAN (38), but employing a different internal standard: cyclohexyl bromide.

SPMA, HMPMA, MHBMA, HEMA, CEMA, and thiocyanate were determined in the SNUS study only.

\section{Questionnaires}

Twelve questionnaire items were used to evaluate the perceived acceptability, sensory properties, and amount of impact sensed in the nose, mouth, throat, and lungs, during smoking of UB cigarettes. Items were completed following UB use during Visit 1 and before smokeless product use during Visits 2, 3, and 4 in all studies. Acceptability was assessed by administering a questionnaire with a picture of a thermometer and gradations every 10 points. Subjects were asked to circle the number that best described their opinion of their UB cigarette. Each number was associated with a rating as follows:

0 - The Very Worst

10 - Terrible

20 - Poor

$30-$ Not Good At All

40 - Not Very Good

50 - Indifferent

60 - Fairly Good

70 - Quite Good

80 - Very Good

90 - Excellent

100 - The Very Best

All other cigarette questionnaire items and anchor point descriptors are listed in Table 9.

Seventeen questionnaire items were also used to assess product acceptability, sensory properties, and the amount of impact sensed in the nose, mouth, throat, lungs, and gastrointestinal (GI) tract during use of Strips, Sticks, and SNUS. These questionnaires were completed by subjects following product use at each visit for the Strips and Sticks studies and after product use during Visits 2, 3, and 4 in the SNUS study (SNUS was not used at Visit 1). Acceptability was assessed by administering a questionnaire with a picture of a thermometer and gradations every 10 points. Subjects were asked to circle the number that best described their opinion of the oral tobacco product they used that week. Each number was associated with a rating as follows:
0 - Can't Use At All

10 - Terrible

20 - Poor

30 - Not Good At All

40 - Not Very Good

50 - Indifferent

60 - Fairly Good

70 - Quite Good

80 - Very Good

90 - Excellent

100 - Perfect

All other questionnaire items and anchor point descriptors for the smokeless products are listed in Table 10.

To evaluate tobacco withdrawal symptoms over the course of the study, subjects completed the Minnesota Nicotine Withdrawal Scale (MNWS) $(39,40)$ at each test visit except Visit 1 for the SNUS study. The first nine of 15 questions measured symptoms of nicotine withdrawal (e.g., depressed, nervous, restless) listed in the Diagnostic and Statistical Manual of Mental Disorders (DSM-IV) (41) and have been validated. Subjects rated each symptom on an ordinal scale of 0 (none) to 4 (severe). The first nine items were summed to create an overall, nicotine withdrawal discomfort score.

\section{Statistical Analysis}

Wilcoxon Sign tests were performed to assess differences in levels of urinary and serum biomarkers, $\mathrm{ECO}, \% \mathrm{COHb}$, and MLEs from cigarettes and STPs for nicotine and NNK from Week 1 to Week 4. A repeated measures ANOVA was used to assess changes from Week 1 to Week 4 in: product use; MLE from cigarettes for nicotine, "tar", and NNK; and MNWS. Paired t-tests were used post hoc to test for significance in the mean differences from the first determination. The $p$-values from the post hoc testing were adjusted for multiple comparisons using Bonferroni's method. The Kendall's $\tau$ test was used to identify monotonically increasing or decreasing trends in questionnaire responses. Questionnaire data were normalized to adjust for individual differences prior to analysis. For each of the questionnaire items, the adjustment performed was

$$
\hat{y}_{i j k}=y_{i j k}-y_{i \cdot k}+y_{\cdot . k}
$$

where

$\hat{y}_{i j k}$ is the adjusted value,

$y_{i j k}$ is the observed response for subject $i$ week $j$ item $k$,

$y_{i \bullet k}$ is the mean for subject $i$ item $k$, and

$y_{. \cdot k}$ is the overall mean for item $k$.

For all tests and comparisons, statistical significance was specified at $p \leq 0.05$. All analyses were performed using $\mathrm{SAS}^{\circledR}$ version 9.1 .3 or higher.

\section{RESULTS}

A total of 100 subjects were enrolled, and 88 subjects completed the studies. Details for each study are shown in Table 2. 
Table 2. Subject details.

\begin{tabular}{|c|c|c|c|c|}
\hline \multicolumn{2}{|c|}{ Demographics } & \multirow{2}{*}{$\begin{array}{l}\text { Strips } \\
32 / 28\end{array}$} & \multirow{2}{*}{$\begin{array}{l}\text { Sticks } \\
32 / 28\end{array}$} & \multirow{2}{*}{$\begin{array}{l}\text { SNUS } \\
36 / 32\end{array}$} \\
\hline $\begin{array}{l}\text { Sample } \\
\text { size }\end{array}$ & enrolled / completed & & & \\
\hline \multirow[t]{2}{*}{ Age } & mean (SD) & $42(10)$ & $41(10)$ & $41(9)$ \\
\hline & range & $23-55$ & $22-55$ & $21-55$ \\
\hline \multirow[t]{2}{*}{ Sex } & number (female / male) & $15 / 13$ & $16 / 12$ & $18 / 14$ \\
\hline & $\%$ (female / male) & $54 / 46$ & $57 / 43$ & $56 / 44$ \\
\hline \multirow{2}{*}{$\begin{array}{l}\text { Years } \\
\text { smoked }\end{array}$} & mean (SD) & $21(11)$ & $20(8)$ & $21(9)$ \\
\hline & range & $4-40$ & $5-40$ & $3-39$ \\
\hline
\end{tabular}

\section{Changes in cigarette and smokeless tobacco consumption rates}

Mean changes in cigarette and smokeless tobacco consumption rates during each stage of cigarette reduction are shown in Table 3. According to subject self-reports, daily cigarette consumption progressively decreased. By the end of Week 4 , mean reductions of $60 \%$ were reported by the Strips and Sticks groups, and $59 \%$ by the SNUS group relative to Week 1 . Weekly reductions in mean cigarette consumption were significant at each stage of reduction $(p<0.05): 22-24 \%$ at the end of Week 2, 41-42\% at Week 3 and 59-60\% at Week 4 compared with mean Week 1 CPD reports.

Mean consumption rates of STPs statistically significantly increased during the Strips and Sticks studies. Relative to the first week of smokeless product use (Week 2), mean usage of Strips increased $83 \%(p=0.0048)$, and mean usage of Sticks increased $130 \%(p=0.0010)$ by the end of Week 4. Although not statistically significant, mean usage of SNUS pouches increased $30 \%(p=0.1101)$ over the same period.

\section{Changes in "tar", nicotine and NNK MLEs from cigarette smoking}

The changes in per-cigarette and daily "tar", nicotine, and NNK MLEs are shown in Table 4. Daily "tar", nicotine, and NNK MLEs from cigarettes decreased during each study. By the end of Week 4, average MLEs were 57-71\% lower than the corresponding Week 1 values. These reductions were similar to the reductions in daily cigarette consumption rates.

"Tar", nicotine, and NNK MLEs per cigarette were relatively unchanged over the course of the study. Per-cigarette MLEs for Week 4 of the Strips and SNUS studies were not statistically significantly different from the corresponding Week 1 values. Small but statistically significant increases in per-cigarette MLEs were observed in "tar" $(13 \%$, $p=0.0020)$, nicotine $(12 \%, p=0.0013)$, and NNK $(12 \%$, $p=0.0243)$ in the Sticks study.

\section{Changes in nicotine and NNK MLEs from total tobacco use}

Because the STPs were also a source of nicotine and NNK (but not "tar" because they are not combusted), the nicotine and NNK daily MLEs from the dual use of cigarettes and smokeless products at Week 4 were compared with corresponding MLEs obtained from Week 1 cigarette smoking to assess changes in MLE from total tobacco use. For the Week 4 dissolvable product MLE estimates, use of Strips and Sticks was assumed to be complete for each unit consumed, and constituent levels from product analyses (Table 1) were applied to the subject reports of Week 4 Day 7 STP consumption. MLE from SNUS was estimated by subtracting the average amount of constituent remaining in the pouches returned by each subject from the amount of constituent present in unused pouches. Individual, perpouch averages were applied to the subject reports of Week 4 Day 7 SNUS use to determine MLE. The mean \pm SD absolute and percentage amounts removed from the pouches by subjects are shown in Table 5. Because total MLE values deviated from normal distributions, total MLE medians, $25^{\text {th }}$, and $75^{\text {th }}$ percentile values for Weeks 1 and 4 are shown in Table 6 . The combination of reduced daily cigarette consumption with dual use of Strips, Sticks, or SNUS resulted in statistically significant reductions in median daily MLE to both nicotine and NNK compared to exposure from Week 1 cigarette smoking.

\section{Changes in urinary NicEq, NNAL-T, 3-HPMA and serum cotinine levels}

Table 7 shows the median, $25^{\text {th }}$, and $75^{\text {th }}$ percentile values for the amounts of NicEq, total NNAL, and 3-HPMA in 24-h urine samples and serum cotinine values obtained at the ends of Week 1 and Week 4. Medians and percentiles

Table 3. Product use over the duration of each study (mean \pm SD).

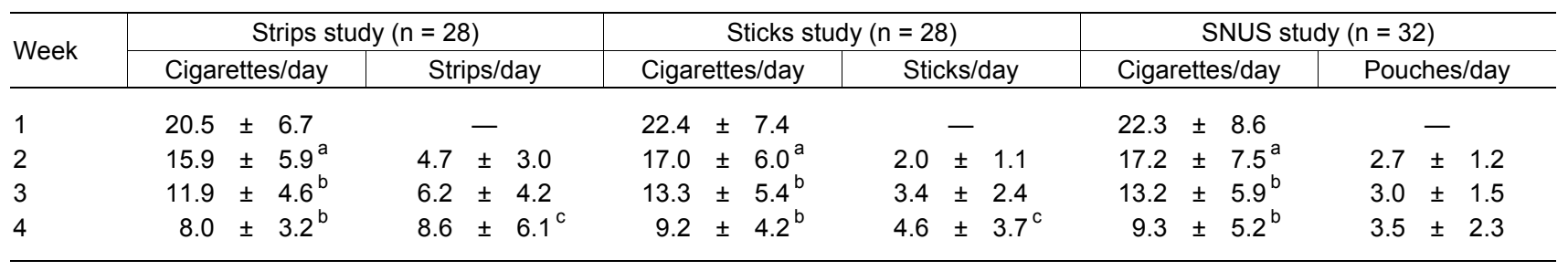

Bonferroni-adjusted statistical significance of differences for pair-wise comparisons with Week 1 for cigarettes and Week 2 for smokeless tobacco products is indicated as:

a $p<0.05$

b $p<0.0001$

c $\quad p<0.01$ 
Table 4. "Tar", nicotine, and NNK mouth-level exposures from cigarettes (mean \pm SD, $p$-values refer to the comparison of Week 1 and Week 4 results (paired t-test)).

\begin{tabular}{|c|c|c|c|c|c|c|}
\hline Cigarette MLE Endpoint & $\mathrm{N}$ & Week 1 & Week 2 & Week 3 & Week 4 & $p$-Value \\
\hline \multicolumn{7}{|l|}{ Strips study } \\
\hline “Tar” per cigarette (mg/cig) & 28 & $16.0 \pm 4.0$ & $16.3 \pm 4.5$ & $16.6 \pm 4.5$ & $16.5 \pm 5.7$ & 0.5280 \\
\hline Daily "tar"(mg/day) & 28 & $304 \pm 128$ & $234 \pm 122$ & $169 \pm 75$ & $118 \pm 70$ & $<0.0001$ \\
\hline Nicotine per cigarette (mg/cig) & 28 & $1.28 \pm 0.3$ & $1.28 \pm 0.3$ & $1.31 \pm 0.3$ & $1.34 \pm 0.4$ & 0.1739 \\
\hline Daily nicotine (mg/day) & 28 & $24.4 \pm 9.7$ & $18.3 \pm 8.7$ & $13.3 \pm 5.6$ & $9.5 \pm 4.9$ & $<0.0001$ \\
\hline NNK (ng/cig) & 16 & $110.1 \pm 36.7$ & $113.7 \pm 40.6$ & $113.9 \pm 37.1$ & $116.5 \pm 42.9$ & 0.0864 \\
\hline Daily NNK (ng/day) & 16 & $2318 \pm 892$ & $1668 \pm 634$ & $1176 \pm 589$ & $771 \pm 362$ & $<0.0001$ \\
\hline \multicolumn{7}{|l|}{ Sticks study } \\
\hline “Tar” per cigarette (mg/cig) & 28 & $18.4 \pm 6.0$ & $18.3 \pm 6.2$ & $19.0 \pm 6.7$ & $20.8 \pm 7.7$ & 0.0020 \\
\hline Daily “tar” (mg/day) & 28 & $381 \pm 159$ & $288 \pm 136$ & $220 \pm 102$ & $164 \pm 84$ & $<0.0001$ \\
\hline Nicotine per cigarette (mg/cig) & 28 & $1.39 \pm 0.5$ & $1.40 \pm 0.5$ & $1.45 \pm 0.5$ & $1.56 \pm 0.6$ & 0.0013 \\
\hline Daily nicotine (mg/day) & 28 & $28.8 \pm 12.5$ & $21.9 \pm 10.8$ & $16.8 \pm 8.2$ & $12.5 \pm 6.9$ & $<0.0001$ \\
\hline NNK (ng/cig) & 12 & $111.5 \pm 67.4$ & $111.1 \pm 71.4$ & $112.2 \pm 66.1$ & $124.8 \pm 78.1$ & 0.0243 \\
\hline Daily NNK (ng/day) & 12 & $1853 \pm 757$ & $1400 \pm 628$ & $1096 \pm 610$ & $803 \pm 580$ & $<0.0001$ \\
\hline \multicolumn{7}{|l|}{ SNUS study } \\
\hline "Tar" per cigarette (mg/cig) & 32 & $13.6 \pm 4.7$ & $12.5 \pm 3.7$ & $13.1 \pm 4.3$ & $13.0 \pm 4.9$ & 0.2367 \\
\hline Daily “tar" (mg/day) & 32 & $274 \pm 122$ & $194 \pm 93$ & $156 \pm 78$ & $109 \pm 66$ & $<0.0001$ \\
\hline Nicotine per cigarette (mg/cig) & 32 & $1.38 \pm 0.5$ & $1.29 \pm 0.4$ & $1.31 \pm 0.4$ & $1.26 \pm 0.5$ & 0.0697 \\
\hline Daily nicotine (mg/day) & 32 & $27.8 \pm 12.3$ & $20.0 \pm 9.9$ & $15.5 \pm 7.7$ & $10.8 \pm 6.6$ & $<0.0001$ \\
\hline NNK (ng/cig) & 15 & $122.4 \pm 41.6$ & $118.0 \pm 42.8$ & $119.6 \pm 43.9$ & $112.8 \pm 43.7$ & 0.1736 \\
\hline Daily NNK (ng/day) & 15 & $2181 \pm 1350$ & $1533 \pm 1147$ & $1125 \pm 801$ & $631 \pm 437$ & 0.0002 \\
\hline
\end{tabular}

Table 5. Constituent mouth-level exposures from SNUS pouches collected by subjects during Weeks 3 and 4 (mean \pm SD).

\begin{tabular}{|c|c|c|c|c|}
\hline Constituent & $\mathrm{N}$ & $\begin{array}{l}\text { Amoun } \\
\text { remove }\end{array}$ & & $\begin{array}{l}\text { Percent } \\
\text { removed }\end{array}$ \\
\hline Nicotine (mg/pouch) & 32 & $1.6 \pm$ & 1.1 & $22.2 \pm 14.7$ \\
\hline Nornicotine ( $\mu \mathrm{g} /$ pouch) & 32 & $20.0 \pm$ & 14.2 & $18.7 \pm 13.1$ \\
\hline Anatabine ( $\mu \mathrm{g} / \mathrm{pouch})$ & 31 & $10.3 \pm$ & 6.1 & $17.0 \pm 10.1$ \\
\hline $\mathrm{B}[\mathrm{a}] \mathrm{P}$ (ng/pouch) & 27 & $0.0 \pm$ & 0.1 & $-6.6^{b} \pm 13.8$ \\
\hline NNN (ng/pouch) & 27 & $78.4 \pm$ & 50.2 & $18.6 \pm 11.9$ \\
\hline NAT (ng/pouch) & 32 & $10.7 \pm$ & 38.8 & $5.2 \pm 19.5$ \\
\hline NAB (ng/pouch) & 32 & $-3.6^{b} \pm$ & 7.5 & $-14.7^{b} \pm 30.5$ \\
\hline NNK (ng/pouch) & 32 & $18.1 \pm$ & 19.1 & $13.4 \pm 13.9$ \\
\hline
\end{tabular}

a Summaries were calculated using one average value per subject if multiple analyses for a single constituent were performed.

b Although a mathematical increase is expected, these results are likely due to intra-product variability for the constituents that are present in very low amounts.

were used because the distributions of urinary biomarkers deviated markedly from normal distributions, and median serum cotinine values are reported for consistency. Percent change is reported as the median of all percent changes for which paired results were available.

No biomarkers showed statistically significant increases at Week 4 compared to Week 1 . Although median total daily nicotine and NNK MLEs significantly decreased from Week 1 to Week 4, the changes in urinary NicEq and NNAL-T typically did not reflect these results. Statistically significant changes in NicEq were not observed, and a small, statistically significant reduction in median NNAL-T was observed in the Strips group. Larger reductions were observed for 3-HPMA in all groups, although only the results for the SNUS group were statistically significant. Serum cotinine values did not statistically significantly change from Week 1 to Week 4.

\section{The effect of dual cigarette and SNUS use on additional biomarkers of exposure}

Several additional urinary biomarkers of exposure were measured in the SNUS study. Median, $25^{\text {th }}$, and $75^{\text {th }}$ percentile values for these biomarkers obtained at the ends of Week 1 and Week 4 are shown in Table 8.

Statistically significant reductions were observed for five of the seven urinary biomarkers of the vapor phase constituents measured (acrolein, benzene, acrylonitrile, ethylene oxide, and thiocyanate) with median decreases in the range of $21-36 \%$ from Week 1 to Week 4 . Additionally, biomarkers of $\mathrm{CO}$ exposure in expired breath (expired $\mathrm{CO}$ ) and whole blood (COHb saturation) were also statistically significantly reduced. Statistically significant decreases in some biomarkers of particulate phase compounds were also observed, including acrylamide, naphthalene, fluorene, 3aminobiphenyl, 4-aminobiphenyl, 2-aminonaphthalene, $o$-toluidine, and NAB. Although not statistically significant, reductions were also observed for biomarkers of particulate phase constituents NAT, NNN, pyrene, and phenanthrene.

\section{Subject opinions of cigarettes and smokeless products}

Statistically significant declining trends in the acceptability of cigarettes were observed for all groups from Week 1 to Week 4 ( $p<0.0001$ for the Strips and SNUS groups, $p<0.0002$ for the Sticks group). Conversely, significant 
Table 6. Changes in daily nicotine and NNK mouth-level exposures from cigarettes (Week 1) and cigarettes plus smokeless products (Week 4).

\begin{tabular}{|c|c|c|c|c|c|c|c|c|c|}
\hline \multirow{2}{*}{ Total MLE endpoint } & \multicolumn{4}{|c|}{ Week 1} & \multicolumn{3}{|c|}{ Week 4} & \multirow{2}{*}{$\begin{array}{l}\text { Median } \\
\text { percent } \\
\text { change }\end{array}$} & \multirow{2}{*}{$p$-Value ${ }^{a}$} \\
\hline & $\mathrm{N}$ & Median & $\mathrm{Q}_{1}^{\mathrm{b}}$ & $\mathrm{Q}_{3}^{\mathrm{b}}$ & Median & $\mathrm{Q}_{1}$ & $\mathrm{Q}_{3}$ & & \\
\hline \multicolumn{10}{|l|}{ Strips study } \\
\hline Daily nicotine (mg/day) & 28 & 23.1 & 18.2 & 29.9 & 11.3 & 9.2 & 14.4 & -45.6 & $<0.0001$ \\
\hline Daily NNK (mg/day) & 16 & 2180 & 1610 & 2840 & 895 & 651 & 1263 & -52.1 & $<0.0001$ \\
\hline \multicolumn{10}{|l|}{ Sticks study } \\
\hline Daily nicotine (mg/day) & 28 & 27.0 & 19.4 & 34.6 & 17.8 & 10.7 & 27.7 & -35.3 & $<0.0001$ \\
\hline Daily NNK (mg/day) & 12 & 1572 & 1247 & 2281 & 1464 & 961 & 2424 & -19.0 & $<0.0001$ \\
\hline \multicolumn{10}{|l|}{ SNUS study } \\
\hline Daily nicotine (mg/day) & 32 & 28.8 & 18.9 & 33.8 & 15.5 & 11.7 & 20.9 & -45.1 & 0.0001 \\
\hline Daily NNK (mg/day) & 15 & 2009 & 1256 & 2812 & 614 & 420 & 1005 & -65.4 & 0.0001 \\
\hline
\end{tabular}

Table 7. Changes in serum cotinine and urinary NicEq, 3-HPMA, and NNAL-T from Week 1 to Week 4.

\begin{tabular}{|c|c|c|c|c|c|c|c|c|c|c|c|}
\hline \multirow{2}{*}{ Biomarker } & \multicolumn{4}{|c|}{ Week 1} & \multicolumn{4}{|c|}{ Week 4} & \multicolumn{2}{|c|}{ Percent change } & \multirow{2}{*}{$p$-Value ${ }^{a}$} \\
\hline & $\mathrm{N}$ & Median & $\mathrm{Q}_{1}^{\mathrm{b}}$ & $\mathrm{Q}_{3}{ }^{\mathrm{b}}$ & $\mathrm{N}$ & Median & $Q_{1}$ & $\mathrm{Q}_{3}$ & $\mathrm{~N}$ & Median & \\
\hline \multicolumn{12}{|l|}{ Strips Study } \\
\hline Cotinine $(\mathrm{ng} / \mathrm{mL})^{\mathrm{c}}$ & 27 & 213.0 & 134.0 & 261.0 & 28 & 218.5 & 139.5 & 298.5 & 27 & $2.0 \%$ & 0.7011 \\
\hline NicEq (mg/24 hr) ${ }^{d}$ & 27 & 17.0 & 10.5 & 20.7 & 27 & 15.6 & 8.6 & 18.0 & 27 & $-4.5 \%$ & 0.1221 \\
\hline 3-HPMA $(\mu \mathrm{g} / 24 \mathrm{hr})^{\mathrm{d}}$ & 27 & 2248 & 1307 & 2853 & 27 & 2069 & 1493 & 2760 & 27 & $-15.6 \%$ & 0.2478 \\
\hline NNAL-T (ng/24 hr) ${ }^{d}$ & 27 & 705.1 & 435.7 & 1249.6 & 27 & 668.7 & 399.6 & 1019.4 & 27 & $-4.5 \%$ & 0.0015 \\
\hline \multicolumn{12}{|l|}{ Sticks Study } \\
\hline Cotinine $(\mathrm{ng} / \mathrm{mL})^{\mathrm{c}}$ & 27 & 256.0 & 166.5 & 378.0 & 27 & 273.0 & 176.0 & 381.0 & 27 & $4.5 \%$ & 0.4421 \\
\hline NicEq $(\mathrm{mg} / 24 \mathrm{hr})^{\mathrm{d}}$ & 24 & 19.0 & 11.9 & 25.9 & 24 & 16.3 & 10.4 & 26.0 & 24 & $-0.2 \%$ & 1.0000 \\
\hline 3-HPMA $(\mu g / 24 h r)^{d}$ & 24 & 235.5 & 1592 & 3365 & 24 & 1805 & 1009 & 3209 & 24 & $-20.0 \%$ & 0.3075 \\
\hline NNAL-T (ng/24 hr) ${ }^{d}$ & 24 & 680.2 & 425.8 & 1238.1 & 24 & 733.3 & 328.5 & 1249.2 & 24 & $0.9 \%$ & 0.8388 \\
\hline \multicolumn{12}{|l|}{ SNUS Study } \\
\hline Cotinine $(\mathrm{ng} / \mathrm{mL})^{\mathrm{c}}$ & 32 & 276.2 & 190.7 & 370.9 & 31 & 253.3 & 205.0 & 377.7 & 31 & $-9.5 \%$ & 1.0000 \\
\hline NicEq $(\mathrm{mg} / 24 \mathrm{hr})^{\mathrm{d}}$ & 30 & 20.5 & 11.9 & 29.1 & 30 & 17.4 & 12.3 & 26.7 & 30 & $-16.0 \%$ & 0.8555 \\
\hline 3-HPMA $(\mu g / 24 h r)^{d}$ & 30 & 2250 & 1420 & 3593 & 30 & 1782 & 1223 & 2857 & 30 & $-23.4 \%$ & 0.0052 \\
\hline NNAL-T (ng/24 hr) ${ }^{d}$ & 30 & 879.3 & 573.4 & 1742.4 & 30 & 972.7 & 507.2 & 1538.7 & 30 & $-8.6 \%$ & 0.2005 \\
\hline $\begin{array}{ll}\text { a } & p \text {-Values refer to } \\
\text { b } & \text { usual brand cigar } \\
\text { c } & Q_{1}, 25^{\text {th }} \text { percentile } \\
\text { d } & \text { Biomarker measu } \\
\text { Biomarker measu }\end{array}$ & in & $\begin{array}{l}\text { ance of } \\
\text { smokele } \\
\text { ercenti } \\
\text { um. } \\
\text { e. }\end{array}$ & $\begin{array}{l}\text { media } \\
\text { roduct }\end{array}$ & $\begin{array}{l}\text { rences } \\
\text { ues. M }\end{array}$ & & ences & $\begin{array}{l}\text { al brar } \\
\text { evalue }\end{array}$ & $\begin{array}{l}\text { larettes } \\
\text { using th }\end{array}$ & & $\begin{array}{l}\text { Week } 4 \text { (du } \\
\text { n Sign test. }\end{array}$ & use of \\
\hline
\end{tabular}

increasing trends in the subjects' opinions of Strips $(p=0.0019)$ and SNUS $(p<0.0001)$ were observed over the course of the study. Although the acceptability of cigarettes decreased and the acceptability of STPs increased, subjects' ratings of cigarettes remained higher than STPs throughout the study. Of the three smokeless products, acceptability of SNUS was rated the highest and acceptability of Sticks was rated the lowest. Mean acceptability ratings are shown in Figure 2.

Additional questionnaire results for cigarettes and STPs are shown in Tables 9 and 10, respectively. A number of the cigarette sensory attributes changed significantly over the course of the study. Subjects reported significant increasing trends of harshness, nose and throat impact, and decreasing trends of smoothness, satisfaction and tobacco taste of UB cigarettes when they switched from exclusive cigarette smoking to dual use of cigarettes and Strips. The same trends were reported in the SNUS study, in addition to increasing trends in strength of taste, strong aftertaste, and chest impact. In the Sticks study, subjects reported significant upward trends of harshness and nose impact and a downward trend for tobacco taste of UB cigarettes.

In contrast to the UB cigarette attributes, fewer STP sensory attributes showed statistically significant changes over time. A significant decreasing trend in the perceived levels of mouth impact from all three types of STPs was observed. Additional significant trends included increasing sweetness and decreasing tobacco taste for Strips, decreasing flavor and throat impact for Strips and Sticks, and increasing bitterness and decreasing mouth burn for SNUS. 
Table 8. Changes in additional biomarkers from Week 1 to Week 4 of the SNUS study.

\begin{tabular}{|c|c|c|c|c|c|c|c|c|c|c|c|c|}
\hline \multirow{2}{*}{ Biomarker } & \multirow{2}{*}{\begin{tabular}{|c|}
$\begin{array}{c}\text { Tobacco } \\
\text { constituent }\end{array}$ \\
\end{tabular}} & \multicolumn{4}{|c|}{ Week 1} & \multicolumn{4}{|c|}{ Week 4} & \multicolumn{2}{|c|}{ \% Change } & \multirow[b]{2}{*}{$p$-Value $^{\mathrm{b}}$} \\
\hline & & $\mathrm{N}$ & Median & $\mathrm{Q}_{1}{ }^{\mathrm{a}}$ & $\mathrm{Q}_{3}{ }^{\mathrm{a}}$ & $\mathrm{N}$ & Median & $\mathrm{Q}_{1}$ & $\mathrm{Q}_{3}$ & $\mathrm{~N}$ & Median & \\
\hline SPMA $(\mu \mathrm{g} / 24 \mathrm{hr})^{\mathrm{c}}$ & benzene & 30 & 7.13 & 2.89 & 10.07 & 30 & 5.62 & 2.27 & 7.27 & 30 & $-29.0 \%$ & 0.0052 \\
\hline HMPMA $(\mu \mathrm{g} / 24 \mathrm{hr})^{\mathrm{c}}$ & crotonaldehyde & 30 & 8545 & 4534 & 13126 & 30 & 6842 & 4471 & 9794 & 30 & $-19.7 \%$ & 0.0987 \\
\hline MHBMA $(\mu \mathrm{g} / 24 \mathrm{hr})^{c}$ & 1,3-butadiene & 26 & 6.48 & 2.70 & 15.32 & 28 & 5.79 & 1.66 & 9.47 & 26 & $-29.8 \%$ & 0.3269 \\
\hline CEMA $(\mu \mathrm{g} / 24 \mathrm{hr})^{\mathrm{c}}$ & acrylonitrile & 30 & 235.9 & 128.0 & 486.2 & 30 & 204.4 & 78.8 & 334.0 & 30 & $-21.4 \%$ & 0.0161 \\
\hline HEMA $(\mu \mathrm{g} / 24 \mathrm{hr})^{\mathrm{c}}$ & ethylene oxide & 30 & 14.03 & 7.29 & 32.29 & 30 & 14.07 & 5.13 & 24.59 & 30 & $-24.8 \%$ & 0.0161 \\
\hline $\begin{array}{l}\text { Thiocyanate } \\
(\mathrm{ng} / 24 \mathrm{hr})^{\mathrm{c}}\end{array}$ & $\mathrm{HCN}$ & 30 & 3456 & 946 & 4293 & 30 & 2232 & 1429 & 3008 & 30 & $-35.7 \%$ & 0.0052 \\
\hline NNN-T (ng/24 hr) & NNN & 30 & 28.0 & 14.8 & 41.6 & 30 & 19.9 & 12.6 & 39.4 & 30 & $-1.8 \%$ & 1.0000 \\
\hline AT-T (ng/24 hr) & NAT & 30 & 456.3 & 298.6 & 828.7 & 30 & 447.7 & 158.9 & 739.5 & 30 & $-18.1 \%$ & 0.0987 \\
\hline NAB-T (ng/24 hr) ${ }^{c}$ & NAB & 30 & 78.8 & 42.9 & 130.3 & 30 & 71.2 & 30.6 & 112.9 & 30 & $-19.8 \%$ & 0.0161 \\
\hline 3-ABP $(n g / 24 \mathrm{hr})^{c}$ & $3-A B P$ & 30 & 9.0 & 6.1 & 16.1 & 30 & 8.3 & 4.7 & 11.8 & 30 & $-28.3 \%$ & 0.0428 \\
\hline -ABP $(\mathrm{ng} / 24 \mathrm{hr})^{\mathrm{c}}$ & 4-ABP & 30 & 24.2 & 14.0 & 34.6 & 30 & 19.3 & 12.1 & 27.7 & 30 & $-12.4 \%$ & 0.0428 \\
\hline 2-AN $(\mathrm{ng} / 24 \mathrm{hr})^{\mathrm{c}}$ & $2-A N$ & 30 & 27.4 & 17.0 & 52.4 & 30 & 26.4 & 15.6 & 36.8 & 30 & $-26.1 \%$ & 0.0014 \\
\hline $\begin{array}{l}\text { o-Toluidine } \\
\text { (ng/24 hr) }^{c}\end{array}$ & dine & 30 & 181. & 1 . & 2 & 30 & 1 & 10 & 203.6 & 30 & -17 & 1 \\
\hline $\begin{array}{l}\text { 1-OH-Naphthalene } \\
(\mu \mathrm{g} / 24 \mathrm{hr})^{c}\end{array}$ & aphthalene & 30 & 13.4 & 6.7 & 21.5 & 30 & 9.9 & 6.0 & 14.7 & 30 & $-26.3 \%$ & 0.0052 \\
\hline $\begin{array}{l}\text { 2-OH-Naphthalene } \\
(\mu \mathrm{g} / 24 \mathrm{hr})^{c}\end{array}$ & naphthalene & 30 & 16.0 & 11.0 & 27.2 & 30 & 13.9 & 7.9 & 21.3 & 30 & $-19.1 \%$ & 0.0052 \\
\hline $\begin{array}{l}\text { 2-OH-Fluorene } \\
\left({ }^{n g / 24 ~ h r}\right)^{c}\end{array}$ & fluorene & 30 & 2436 & 1218 & 3952 & 29 & 2335 & 1319 & 2512 & 29 & $-25.6 \%$ & 0.0241 \\
\hline $\begin{array}{l}\text { 1-OH-Phenanthrene } \\
(\mathrm{ng} / 24 \mathrm{hr})^{\mathrm{c}}\end{array}$ & phenanthrene & 30 & 219.3 & 120.6 & 371.7 & 28 & 200.0 & 150.2 & 278.1 & 28 & $-8.0 \%$ & 0.5716 \\
\hline $\begin{array}{l}\text { 2-OH-Phenanthrene } \\
(\mathrm{ng} / 24 \mathrm{hr})^{\mathrm{c}}\end{array}$ & phenanthrene & 30 & 175.1 & 84.4 & 275.5 & 28 & 127.9 & 63.4 & 187.0 & 28 & $-16.0 \%$ & 0.4421 \\
\hline $\begin{array}{l}\text { 3-OH-Phenanthrene } \\
(\mathrm{ng} / 24 \mathrm{hr})^{\mathrm{c}}\end{array}$ & phenanthrene & 30 & 268.1 & 137.2 & 457.6 & 29 & 265.4 & 171.4 & 373.7 & 29 & $22.0 \%$ & 0.4583 \\
\hline $\begin{array}{l}\text { 4-OH-Phenanthrene } \\
(\mathrm{ng} / 24 \mathrm{hr})^{\mathrm{c}}\end{array}$ & phenanthrene & 30 & 41.8 & 22.7 & 66.2 & 29 & 45.8 & 24.8 & 59.2 & 29 & $-8.5 \%$ & 1.0000 \\
\hline $\begin{array}{l}\text { 9-OH-Phenanthrene } \\
\text { (ng/24 hr) }\end{array}$ & phenanthrene & 30 & 182.7 & 92.9 & 340.8 & 29 & 184.6 & 108.6 & 246.0 & 29 & $-4.0 \%$ & 0.7111 \\
\hline $\begin{array}{l}\text { 1-OH-Pyrene } \\
(\mathrm{ng} / 24 \mathrm{hr})^{\mathrm{c}}\end{array}$ & yrene & 30 & 225.9 & 111.3 & 423.9 & 29 & 232.3 & 161.2 & 340.8 & 29 & $-5.8 \%$ & 0.4583 \\
\hline AAMA $(\mu \mathrm{g} / 24 \mathrm{hr})^{\mathrm{c}}$ & acrylamide & 30 & 296.3 & 188.9 & 427.6 & 30 & 245.5 & 180.6 & 372.3 & 30 & $-21.0 \%$ & 0.0428 \\
\hline GAMA $(\mu \mathrm{g} / 24 \mathrm{hr})^{c}$ & acrylamide & 30 & 40.4 & 34.4 & 68.7 & 30 & 40 & 27.9 & 51.5 & 30 & $-19.3 \%$ & 0.0003 \\
\hline Expired CO (ppm) ${ }^{d}$ & carbon monoxide & 31 & 28 & 16 & 47 & 31 & 24 & 14 & 39 & 30 & $-17.2 \%$ & 0.0081 \\
\hline $\begin{array}{l}\mathrm{COHb} \\
(\% \text { saturation })^{\mathrm{e}}\end{array}$ & carbon monoxide & 32 & 6.6 & 4.4 & 8.7 & 32 & 6.0 & 4.2 & 8.2 & 32 & $-14.4 \%$ & 0.0070 \\
\hline
\end{tabular}

a $\quad Q_{1}, 25^{\text {th }}$ percentile; $Q_{3}, 75^{\text {th }}$ percentile

b $\quad p$-Values refer to the significance of the median differences between Week 1 (usual brand cigarettes only) and Week 4 (dual use of usual brand cigarettes and smokeless products) values. Median differences were evaluated using the Wilcoxon Sign test.

c Measured in urine.

d Measured in expired breath.

e Measured in blood.

\section{MNWS results}

Despite the reported reductions in daily cigarette consumption rates, no significant trends in the mean MNWS discomfort scores were observed when subjects switched from cigarettes only to dual use of cigarettes and either Strips, Sticks or SNUS (data not shown.)

\section{Adverse Events}

Commonly reported adverse events included mild and moderate experiences of throat, mouth, gum or tongue irritation, hiccups, indigestion, nausea, cough, and headache. These adverse events generally subsided within 3-30 min after product use.

\section{DISCUSSION}

These studies were designed to examine changes in various study endpoints - biomarkers of tobacco exposure; "tar", nicotine, and NNK MLEs; and subjective product ratings when subjects switched from solely smoking cigarettes to dual use of cigarettes and one type of STP. To achieve this, subjects were instructed to incrementally decrease CPD over a three-week period and use either Strips, Sticks, or SNUS.

Subjects in these studies purchased their UB cigarettes for use and were provided with Strips, Sticks, or SNUS at no cost. These differences may have influenced their product use choices; however, this study was not designed to assess the effect of those differences on the study outcomes.

Subjects reported successful reductions in CPD and 


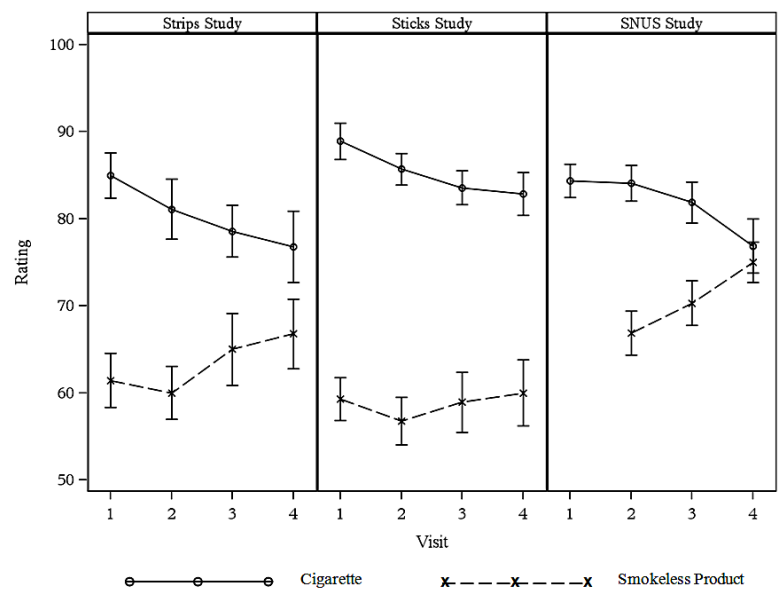

Figure 2. Mean product acceptability ratings. Error bars indicate standard error. Ratings for SNUS were not obtained at Visit 1 because in-clinic SNUS use occurred at Visits 2, 3, and 4 only.

transitions to dual use. Significant reductions in average CPD of 22-25\% (Week 2), 41-42\% (Week 3) and 59-60\% (Week 4) were reported. The week-by-week reductions in cigarette consumption were accompanied by increases in the number of Strips, Sticks, or SNUS pouches used.

Biomarkers of tobacco exposure were measured in 24-h urine collections in all studies. In the Strips and Sticks studies, measures of biomarkers for nicotine and NNK were chosen to understand exposure changes across all tobacco products because both compounds are specific to tobacco and are found in cigarettes and STPs. Acrolein was chosen to understand changes in cigarette smoke exposure because it is a product of tobacco combustion that indicates some degree of cigarette smoke inhalation has occurred. In the SNUS study, biomarkers for the three toxicants listed above were measured, as well as a more extensive list of compounds, some of which are found in the particulate phase of smoke and some are specific to the vapor phase. Although most of the additional biomarkers are not tobacco-specific, tobacco use is the primary source of exposure rather than environmental or dietary sources. Measurements of the additional biomarkers chosen in the SNUS study were performed to obtain a more fulsome measure of tobacco exposure changes from Week 1 to Week 4.

Biomarkers for nicotine, NNK, and acrolein measured in 24-h urine collections for all studies either decreased or showed no statistically significant change after subjects switched to dual use. Of the additional urinary biomarkers measured in the SNUS study, metabolites of five of seven

Table 9. Mean sensory attribute scores for usual brand cigarettes at all Visits.

\begin{tabular}{|c|c|c|c|c|c|c|c|c|c|c|c|c|c|c|c|}
\hline \multirow{2}{*}{$\begin{array}{c}\text { Question / } \\
\text { attribute }\end{array}$} & \multirow{2}{*}{ Scale } & \multirow{2}{*}{ Low anchor } & \multirow{2}{*}{ High anchor } & \multicolumn{4}{|c|}{ Strips study } & \multicolumn{4}{|c|}{ Sticks study } & \multicolumn{4}{|c|}{ SNUS study } \\
\hline & & & & $\mathrm{V} 1^{\mathrm{a}}$ & V2 & V3 & V4 & $\mathrm{V} 1$ & V2 & V3 & V4 & V1 & V2 & V3 & V4 \\
\hline $\begin{array}{l}\text { Strength of } \\
\text { taste }\end{array}$ & $1-7$ & $\begin{array}{l}\text { not strong } \\
\text { tasting at all }\end{array}$ & $\begin{array}{l}\text { extremely } \\
\text { strong tasting }\end{array}$ & 4.2 & 3.9 & $\begin{array}{l}4.0 \\
p=0\end{array}$ & $\begin{array}{c}3.9 \\
1003\end{array}$ & 4.0 & 3.5 & $\begin{array}{l}3.8 \\
p=C\end{array}$ & $\begin{array}{c}3.8 \\
5284\end{array}$ & 4.2 & 3.8 & $\begin{array}{l}3.7 \\
p=0\end{array}$ & $\begin{array}{c}3.8 \\
0281\end{array}$ \\
\hline $\begin{array}{l}\text { Smoke through } \\
\text { filter }\end{array}$ & $1-7$ & $\begin{array}{c}\text { extremely easy } \\
\text { to get smoke } \\
\text { through filter }\end{array}$ & $\begin{array}{c}\text { extremely hard } \\
\text { to get smoke } \\
\text { through filter }\end{array}$ & 2.9 & 2.6 & $\begin{array}{l}2.9 \\
p=0\end{array}$ & $\begin{array}{c}2.9 \\
6522\end{array}$ & 2.9 & 2.6 & $\begin{array}{l}2.7 \\
p=c\end{array}$ & $\begin{array}{c}2.6 \\
2577\end{array}$ & 3.0 & 3.0 & $\begin{array}{l}2.8 \\
p=0\end{array}$ & $\begin{array}{c}2.7 \\
5941\end{array}$ \\
\hline Harsh & $1-7$ & $\mathrm{~h}$ at all & $\begin{array}{l}\text { extremely } \\
\text { harsh }\end{array}$ & 1.8 & 2.5 & $\begin{array}{l}3.0 \\
p=0\end{array}$ & $\begin{array}{c}2.8 \\
0002\end{array}$ & 2.3 & 2.5 & $\begin{array}{l}2.7 \\
p=c\end{array}$ & $\begin{array}{c}2.7 \\
0342\end{array}$ & 2.3 & 2.8 & $\begin{array}{l}2.9 \\
p<0\end{array}$ & $\begin{array}{c}3.3 \\
0001\end{array}$ \\
\hline Smooth & $1-7$ & $\begin{array}{l}\text { not smooth at } \\
\text { all }\end{array}$ & $\begin{array}{l}\text { extremely } \\
\text { smooth }\end{array}$ & 5.1 & 5.0 & $\begin{array}{l}4.6 \\
p=0\end{array}$ & $\begin{array}{c}4.1 \\
0053\end{array}$ & 5.6 & 5.4 & $\begin{array}{l}5.0 \\
p=c\end{array}$ & $\begin{array}{c}5.4 \\
2159\end{array}$ & 5.5 & 4.7 & $\begin{array}{l}4.8 \\
p<0\end{array}$ & $\begin{array}{c}4.5 \\
0001\end{array}$ \\
\hline Satisfying & $1-7$ & $\begin{array}{l}\text { not satisfying } \\
\text { at all }\end{array}$ & $\begin{array}{l}\text { extremely } \\
\text { satisfying }\end{array}$ & 6.1 & 5.7 & $\begin{array}{l}5.5 \\
p<0\end{array}$ & $\begin{array}{c}4.8 \\
0001\end{array}$ & 6.2 & 5.9 & $\begin{array}{l}5.6 \\
p=c\end{array}$ & $\begin{array}{c}6.0 \\
0820\end{array}$ & 6.1 & 5.5 & $\begin{array}{l}5.3 \\
p<0\end{array}$ & $\begin{array}{c}5.0 \\
.0001\end{array}$ \\
\hline Tobacco taste & $1-7$ & $\begin{array}{l}\text { no tobacco } \\
\text { taste }\end{array}$ & $\begin{array}{l}\text { extremely } \\
\text { strong tobacco } \\
\text { taste }\end{array}$ & 4.9 & 4.3 & $\begin{array}{l}4.4 \\
p=0\end{array}$ & $\begin{array}{c}4.0 \\
0029\end{array}$ & 4.9 & 4.5 & $\begin{array}{l}4.3 \\
p<c\end{array}$ & $\begin{array}{c}4.1 \\
0001\end{array}$ & 4.7 & 4.3 & $\begin{array}{l}4.2 \\
p=0\end{array}$ & $\begin{array}{c}4.2 \\
0130\end{array}$ \\
\hline $\begin{array}{l}\text { Strong } \\
\text { aftertaste }\end{array}$ & $1-7$ & no aft & $\begin{array}{l}\text { extremely } \\
\text { strong } \\
\text { aftertaste }\end{array}$ & 3.4 & 3.5 & $\begin{array}{l}3.5 \\
p=0\end{array}$ & $\begin{array}{c}3.5 \\
6878\end{array}$ & 2.9 & 2.9 & $\begin{array}{l}3.1 \\
p=c\end{array}$ & $\begin{array}{c}3.1 \\
4797\end{array}$ & 3.3 & 3.2 & $\begin{array}{l}3.3 \\
p=0\end{array}$ & $\begin{array}{c}3.8 \\
.0045\end{array}$ \\
\hline Nose impact & $1-8$ & none & extreme & 2.1 & 2.7 & $\begin{array}{l}2.9 \\
p=0\end{array}$ & $\begin{array}{c}2.9 \\
0029\end{array}$ & 1.4 & 1.6 & $\begin{array}{l}2.1 \\
p=c\end{array}$ & $\begin{array}{c}1.9 \\
0237\end{array}$ & 1.9 & 2.4 & $\begin{array}{l}2.3 \\
p=0\end{array}$ & $\begin{array}{r}2.8 \\
0010\end{array}$ \\
\hline Mouth impact & $1-8$ & none & extreme & 3.9 & 3.6 & $\begin{array}{l}3.6 \\
p=0\end{array}$ & $\begin{array}{c}3.6 \\
6766\end{array}$ & 3.0 & 2.9 & $\begin{array}{l}2.9 \\
p=c\end{array}$ & $\begin{array}{c}3.7 \\
1360\end{array}$ & 3.5 & 3.3 & $\begin{array}{l}3.2 \\
p=0\end{array}$ & $\begin{array}{c}3.4 \\
5757\end{array}$ \\
\hline Throat impact & $1-8$ & none & extreme & 2.6 & 3.4 & $\begin{array}{l}3.3 \\
p=0\end{array}$ & $\begin{array}{c}3.4 \\
0259\end{array}$ & 3.0 & 2.9 & $\begin{array}{l}2.8 \\
p=c\end{array}$ & $\begin{array}{c}2.8 \\
6421\end{array}$ & 3.3 & 2.8 & $\begin{array}{l}3.4 \\
p=0\end{array}$ & $\begin{array}{c}3.4 \\
4627\end{array}$ \\
\hline Chest impact & $1-8$ & none & extreme & 3.1 & 3.3 & $\begin{array}{l}3.7 \\
p=0\end{array}$ & $\begin{array}{c}3.8 \\
0509\end{array}$ & 3.3 & 3.0 & $\begin{array}{l}3.6 \\
p=c\end{array}$ & $\begin{array}{c}3.5 \\
1139\end{array}$ & 3.4 & 3.0 & $\begin{array}{l}3.4 \\
p=C\end{array}$ & $\begin{array}{c}4.0 \\
0243\end{array}$ \\
\hline
\end{tabular}

a V1 - Visit 1; V2 - Visit 2; V3 - Visit 3; V4 - Visit 4 
Table 10. Mean sensory attribute scores for smokeless tobacco products at all Visits.

\begin{tabular}{|c|c|c|c|c|c|c|c|c|c|c|c|c|c|c|}
\hline \multirow{2}{*}{ Question / Attribute } & \multirow{2}{*}{ Scale } & \multirow{2}{*}{ Low anchor } & \multirow{2}{*}{ High anchor } & \multicolumn{4}{|c|}{ Strips study } & \multicolumn{4}{|c|}{ Sticks study } & \multicolumn{3}{|c|}{ SNUS study } \\
\hline & & & & $\mathrm{V} 1^{\mathrm{a}}$ & V2 & V3 & V4 & V1 & $\mathrm{V} 2$ & V3 & V4 & V2 & V3 & V4 \\
\hline \multirow[t]{2}{*}{ Sweetness } & $1-7$ & too little & too much & 3.6 & 3.8 & 3.9 & 4.0 & 3.7 & 3.6 & 3.6 & 3.6 & 4.2 & 4.0 & 4.0 \\
\hline & & & & & \multicolumn{3}{|c|}{$p=0.0401$} & & \multicolumn{3}{|c|}{$p=0.4409$} & \multicolumn{3}{|c|}{$p=0.0619$} \\
\hline \multirow[t]{2}{*}{ Flavor } & $1-7$ & too little & too much & 5.0 & 4.9 & 4.9 & 4.6 & 4.9 & 4.8 & & 4.4 & 4.6 & & 4.3 \\
\hline & & & & & \multicolumn{3}{|c|}{$p=0.0013$} & & \multicolumn{3}{|c|}{$p=0.0058$} & \multicolumn{3}{|c|}{$p=0.0793$} \\
\hline \multirow[t]{2}{*}{ Tobacco taste } & $1-7$ & too little & too much & 4.7 & 4.8 & 4.7 & 4.4 & 4.9 & 5.1 & & 4.9 & 3.7 & & 3.9 \\
\hline & & & & & \multicolumn{3}{|c|}{$p=0.0002$} & & \multicolumn{3}{|c|}{$p=0.5507$} & \multicolumn{3}{|c|}{$p=0.4431$} \\
\hline \multirow[t]{2}{*}{ Texture } & $1-7$ & too slimy & too coarse & 3.7 & 3.5 & 3.5 & 3.5 & 3.8 & 3.6 & & 3.9 & 3.8 & & 3.7 \\
\hline & & & & & \multicolumn{3}{|c|}{$p=0.1843$} & & \multicolumn{3}{|c|}{$p=0.9131$} & \multicolumn{3}{|c|}{$p=0.5708$} \\
\hline \multirow[t]{2}{*}{ Bitterness } & $1-7$ & none & extreme & 3.0 & 3.1 & 2.8 & 2.8 & 3.3 & 3.6 & & 3.2 & 2.1 & 2.3 & 2.7 \\
\hline & & & & & \multicolumn{3}{|c|}{$p=0.2895$} & & & $p=0$. & 1160 & & $p=0$ & 0011 \\
\hline Mouth burn & $1-7$ & none & extreme & 2.9 & 3.1 & 2.6 & 2.9 & 3.4 & 3.4 & 3.8 & 3.4 & 3.9 & 3.0 & 3.0 \\
\hline & & & & & & $p=0$ & 7372 & & & $p=0$. & 3857 & & $p=0$ & 0108 \\
\hline Throat burn & $1-7$ & none & extreme & 2.9 & 3.4 & 2.8 & 2.7 & 4.0 & 3.8 & 3.8 & 3.4 & 2.6 & 2.6 & 2.9 \\
\hline & & & & & & $p=0$ & 4674 & & & $p=0$. & 9914 & & $p=0$ & 5425 \\
\hline Side effects & $1-7$ & none & extreme & 1.6 & 2.0 & 2.0 & 1.8 & 1.5 & 2.0 & 1.8 & 2.2 & 2.1 & 2.3 & 2.0 \\
\hline & & & & & & $p=0$ & 4095 & & & $p=0$. & 645 & & $p=0$ & 2829 \\
\hline Aftertaste & $1-7$ & unpleasant & pleasant & 3.9 & 3.8 & 4.1 & 4.1 & 4.1 & 3.6 & 3.5 & 3.7 & 4.4 & 4.8 & 4.9 \\
\hline & & & & & & $p=0$ & 2483 & & & $p=0$. & 7776 & & $p=0$ & 1016 \\
\hline Overall taste & $1-7$ & unpleasant & pleasant & 4.1 & 4.0 & 4.1 & 4.2 & 3.9 & 3.6 & 3.8 & 3.8 & 4.9 & 5.2 & 5.0 \\
\hline & & & & & & $p=0$ & 3729 & & & $p=0$. & 5620 & & $p=0$ & 7500 \\
\hline Overall likeability & $1-7$ & hate it & love it & 4.1 & 4.3 & 4.4 & 4.4 & 4.1 & 3.6 & 4.1 & 4.0 & 4.4 & 4.9 & 4.7 \\
\hline & & & & & & $p=0$ & 4006 & & & $p=0$. & 5450 & & $p=0$ & 1808 \\
\hline Nose impact & $1-8$ & none & extreme & 0.2 & 0.4 & 0.2 & 0.3 & 0.3 & 0.3 & 0.3 & 0.4 & 0.6 & 0.5 & 0.6 \\
\hline & & & & & & $p=0$ & 3777 & & & $p=0$. & 3478 & & $p=0$ & 5726 \\
\hline Mouth impact & $1-8$ & none & extreme & 5.2 & 4.4 & 4.1 & 3.9 & 4.7 & 4.6 & 4.5 & 3.8 & 4.7 & 4.0 & 3.6 \\
\hline & & & & & & $p<0$ & 0001 & & & $p=0$. & 000 & & $p=0$ & 0017 \\
\hline Throat impact & $1-8$ & none & extreme & 3.6 & 3.8 & 3.4 & 2.8 & 4.6 & 3.6 & 3.5 & 3.2 & 2.8 & 2.7 & 3.2 \\
\hline & & & & & & $p=0$ & 0065 & & & $p=0$. & 0004 & & $p=0$ & 3267 \\
\hline Chest impact & $1-8$ & none & extreme & 0.5 & 0.8 & 0.3 & 0.3 & 0.6 & 0.4 & 0.6 & 0.5 & 0.4 & 0.6 & 0.8 \\
\hline & & & & & & $p=0$ & 1203 & & & $p=0$. & 266 & & $p=0$ & 1318 \\
\hline GI tract impact & $1-8$ & none & extreme & 0.9 & 1.3 & 1.3 & 0.8 & 1.3 & 1.3 & 1.5 & 1.4 & 1.5 & 1.7 & 1.7 \\
\hline & & & & & & $p=0$ & 5873 & & & $p=0$. & 2792 & & $p=0$ & 5542 \\
\hline
\end{tabular}

a V1 - Visit 1; V2 - Visit 2; V3 - Visit 3; V4 - Visit 4

vapor phase constituents statistically significantly decreased in the range of $21-36 \%$. Biomarkers of carbon monoxide exposure in blood ( $\mathrm{COHb}$ saturation) and expired air (ECO) also significantly decreased 14-17\%. Similar to the vapor phase constituents, statistically significant reductions of $18-28 \%$ in biomarkers of particulate phase compounds acrylamide, naphthalene, fluorene, 3aminobiphenyl, 4-aminobiphenyl, 2-aminonaphthalene, $o$ toluidine, and NAB were observed. Although not statistically significant, reductions were also observed for biomarkers of particulate phase constituents NAT, NNN, pyrene, and phenanthrene. Together, these results suggest that tobacco exposure did not increase as subjects switched to dual use, and smoke exposure likely decreased.

Biomarker changes in all studies were generally not as great as the reported CPD reductions or the estimated MLE reductions for nicotine and NNK. A number of other researchers have reported the results of studies that measured the effects of lowering daily cigarette consumption rates on the levels of biomarkers of cigarette smoke exposure. Many of them have also reported smaller reductions in biomarkers of exposure than would have been predicted from the decreased level of cigarette consumption (e.g., 8-10; 42-47). In particular, studies of smokers in clinical confinement randomized to tobacco abstinent groups showed statistically significant reductions in all biomarkers of exposure measured in 24-hour urine samples; however, for most biomarkers, residual levels remained after 5 days of abstinence and the extent of the reductions observed was dependent on the biomarker $(9,10,47)$.

The authors of some cigarette reduction studies have hypothesized that the smokers may have compensated for 
the reduction in the number of cigarettes smoked per day by increasing their smoking intensity of the remaining cigarettes $(44,45)$. Results from short-term confinement studies show increases in MLE of $0 \%$ to $28 \%$ on a percigarette basis using the partial filter tip analysis method for nicotine and "tar". When increases occurred, the amount of increase was generally related to the magnitude of CPD reductions $(9,10,47)$. In the studies reported here, percigarette "tar", nicotine, and NNK MLEs did not significantly change from baseline to Week 4 in the Strips and SNUS groups and showed small increases in the Sticks group. In addition, daily nicotine, "tar", and NNK MLEs decreased in proportion to decreases in CPD during dual use. Together, these results indicate a lack of compensatory smoking behavior.

Several studies have reported biomarker and/or MLE results for smokers who switch to dual use with a STP while in clinical confinement. KRAUTTER and BORGERDING (9) reported results for a group of smokers who were switched to dual use of cigarettes and STPs under a work day-like study design that limited the times of day smoking was permitted but did not restrict the number of cigarettes or STPs. During the non-smoking periods (and throughout the day), the smokers were permitted to use Camel Orbs. Results of that switch showed a small CPD decrease of approximately $11 \%$. Similar to the results of the studies described in this paper, no biomarkers showed statistically significant increases after the switch to dual product use. Urinary NicEq and total NNAL did not statistically significantly change from baseline. Additional comparisons can be made to the longer list of biomarkers measured in the SNUS study that were also measured by KRAUTTER and BORGERDING (9). Results from the SNUS study reported here showed larger statistically significant decreases in SPMA (-29.0\% vs. $-16.9 \%)$, 2-OH-fluorene (-25.6\% vs. $-4.8 \%)$, 3-ABP (-28.3\% vs. $-15.7 \%)$, 2-AN (-26.1\% vs. $-17.7 \%), 2-\mathrm{OH}-$ naphthalene $(-19.1 \%$ vs. $-10.7 \%)$, and AAMA $(-21.0 \%$ vs. $-2.6 \%)$ than those reported by KRAUTTER and BORGERDING (9). Similar statistically significant decreases were observed for 4-ABP, GAMA, and 1-OH-naphthalene in the two studies. In addition, HPMA and $o$-toluidine statistically significantly decreased in the SNUS study ( $-23.4 \%$ and $-17.8 \%$, respectively), but no statistically significant changes were reported in those biomarkers by KRAUTTER and BORGERDING (9). The comparisons of the vapor phase-constituent and combustion-specific biomarkers suggest that actual CPD reductions were likely greater in the SNUS study, and comparisons of biomarkers overall suggest that tobacco constituent exposure was decreased by a larger amount in those smokers who participated in the SNUS study.

KRAUTTER et al. (10) reported results of a clinical confinement study in which smokers were switched to dual use with product-use outcomes that were nearly identical to those reported here in the SNUS study. In that study, smokers switched to dual use with Camel SNUS and reduced CPD by $60 \%$ but were housed in clinic for the fiveday switch rather than completing the study at home. Biomarkers of tobacco exposure were assessed in 24-hour urine samples collected during baseline ad libitum smoking and after 5 days of dual use. Similar biomarkers were measured in the two studies and MLE was also assessed.
Mean CPD at baseline and during dual use were slightly lower than results reported here (19.2 vs. $22.3 \mathrm{CPD}$ and 7.6 vs. $9.3 \mathrm{CPD}$, respectively). SNUS use was similar in the two studies (3.2 pouches per day vs. 3.5 pouches per day in Week 4 of the SNUS study).

Results from KRAUTTER et al. (10) showed larger reductions in most biomarkers than the SNUS study results reported here, by roughly 2 -fold. In particular, NicEq decreased $31.8 \%$ vs. a non-statistically significant decrease of $16 \%$ in the SNUS study. These results suggest that tobacco exposure in the ambulatory SNUS study did not decrease to the same degree as exposure while subjects were in clinical confinement, although greater smoking compensation, as assessed by per-cigarette MLE changes, was reported by KRAUTTER et al. (10). The differences in biomarker changes from baseline to dual use in the two studies may be due to a number of factors, including differences in absolute CPD numbers, differences in percigarette MLE, differences in metabolic activity of the subjects, or the accurate accountability of product use while in confinement.

KRAUTTER et al. (10) reported statistically significant percigarette increases of $27-28 \%$ in MLE to nicotine and "tar", while no statistically significant changes were observed in the SNUS study. Because increases in per-cigarette MLE would be expected to increase biomarker levels rather than decrease them, the differences in MLE results do not explain the differences in biomarker reductions in the two studies.

Reporting of product use by subjects in the studies reported here may be less accurate, especially for cigarettes, given that the reductions in vapor phase biomarkers were also greater in the dual use group of KRAUTTER et al. (10). Given that no compensatory smoking changes occurred in the ambulatory setting, but small statistically significant changes occurred while in confinement also suggests the possibility that smokers in the ambulatory studies may have smoked more cigarettes than they reported, and therefore changed their smoking behavior less than indicated. If so, the results reported here may be more likely to reflect biomarker changes that might occur if a smoker were to reduce CPD by a smaller amount than reported.

In contrast to those studies reporting disproportionate reductions in CPD consumption and biomarkers of cigarette smoke exposure levels, SARKAR et al. (8) reported proportional reductions in CPD and a number of biomarkers in an eight-day study with in-clinic confinement. After collecting baseline measurements of biomarkers, one group of smokers reduced their daily cigarette consumption by an average of $50 \%$ and was allowed dual use of cigarettes and Marlboro Snus. A second group of smokers abstained from all tobacco use during the eight-day period. The residual levels of biomarkers measured at the end of the study in the abstinent group were used to adjust the biomarker levels of the dual-use group. This adjustment removed the effect of environmental exposure, variable biomarker half-lives, and potential differences in metabolism from subject to subject to allow for a more direct assessment of changes in exposure to tobacco constituents. Following this adjustment, most of the biomarkers of exposure to cigarette smoke in the dual-use group decreased proportionately to CPD consumption. Therefore, SARKAR et al. (8) concluded that 
the dual use of cigarettes and Marlboro Snus did not result in compensatory changes in smoking behavior. Of note, 22 of the 60 subjects in the dual-use group reduced cigarette consumption but did not use Marlboro Snus during the study, which suggests that CPD reductions alone also did not result in compensatory smoking.

Mouth-level exposure was examined in the ambulatory studies reported here to assess whether changes in puffing behavior may have contributed to the biomarker changes observed. Although minimal changes were observed, mechanisms of smoking behavior compensation other than changes in puffing behavior should also be considered. Cigarette smoke particulate phase deposition and retention in the respiratory tract are increased for some constituents when post-puff inhalation durations and volumes are increased $(48,49)$. Therefore, increases in post-puff inhalation depth during the periods when daily cigarette consumptions were reduced could, in part, account for discrepancies between MLEs and levels of biomarkers of exposure from cigarette smoke particulate phase constituents. FENG et al. (49) reported increases in the respiratory retentions of particulate phase constituents NNK and NNN when smokers changed from a routine inhalation to a deep post-puff inhalation. Consequently, an increase in post-puff inhalation depths when cigarette consumption rates were reduced could be a factor responsible for observed differences between the reductions in NNK MLEs and urinary NNAL levels. However, changes in post-puff inhalation depths and duration have little effect on the respiratory retention of nicotine $(48,49)$ and are unlikely to influence the retentions of acrolein, crotonaldehyde and benzene, as these vapor phase constituents are retained at very high levels during typical post-puff inhalations $(50,51)$. Thus, differences between changes in total daily nicotine MLE and urinary NicEq and serum cotinine are unlikely to be explained by changes in post-puff inhalation patterns. Similarly, changes in post-puff inhalation patterns would not explain the discrepancies between reported CPD reductions and the urinary biomarkers of vapor phase constituents.

Changes in 'mouth spill' may also alter the relationships between MLEs and levels of biomarkers of exposure. 'Mouth spill' is defined as the amount of smoke expelled from the mouth in the interval between the end of a puff and start of post-puff inhalation. If smokers reduced 'mouth spill' as cigarette consumption decreased, smoke exposure per cigarette would increase and produce a discrepancy between MLE and biomarker levels. No published data exist that quantify 'mouth spill,' therefore its role as a possible component of compensatory smoking remains uncertain.

Factors other than smoking behavior changes should be examined when comparing MLEs to levels of biomarkers of exposure. In the studies reported here, subjects were not confined to a clinic during the course of the study. A potential drawback of this ambulatory design is that product use behaviors were not directly observed, and CPD data were self-reported. Consequently, disparities between the levels of reductions in measured biomarkers and self-reported cigarette consumption may be at least partially explained by subjects under-reporting their smoking levels during the smoking reduction periods. This possibility is supported by results from a recent confinement study in which smokers experienced a similar reduction in CPD but a greater reduc- tion in biomarker levels (10). In the studies reported here, subjects were instructed to rigorously maintain daily product use logs of cigarettes smoked and STPs consumed; however, reports of subject noncompliance with paper diary reporting are well-established $(52,53)$. Nevertheless, each study enrolled an independent group of subjects, and each of these groups reported achieving approximately $60 \%$ mean reduction in CPD consumption at Week 4.

Metabolic factors may also play a role in observed differences in reductions. This is particularly important for NNK. NNAL and NNAL-glucuronide were determined by HECHT et al. $(54,55)$ to have a terminal half-life of $26-45$ days and by GONIEWICZ et al. (56) to have a terminal half-life of 10-18 days. Due to the long half-life of this biomarker, a longer duration of maximum CPD reduction with concurrent STP use would be required for NNAL-T levels to equilibrate to reflect actual exposure changes. Hence, we expect reductions in NNAL-T levels to be smaller than CPD reductions based on the study design. However, the long half-life is unlikely to fully account for why NNK MLE reductions are greater than the corresponding reductions in urinary NNAL-T levels.

The assessments of the sensory properties and overall opinions of UB cigarettes and the three STPs produced notable results. First, although they were scored as being less acceptable than cigarettes, mean ratings of the three smokeless products at study completion were between 60 and 75 on a scale of 100 . Secondly, the acceptability ratings of UB cigarettes declined steadily over each week of the study, whereas the ratings of Strips and SNUS increased. The decline in the cigarette rating was associated with the tendency for subjects to perceive cigarettes as increasing in harshness and in nose and throat impacts and becoming less satisfying as their daily consumption rates dropped. Thirdly, subjects rated SNUS as being the most acceptable, and Sticks the least acceptable, of the three STPs. By Week 4, the subjects' overall opinion of SNUS was only marginally lower than their opinion of their UB cigarettes. The reduced acceptability of cigarettes suggests a potential reinforcing effect of product migration and/or decreasing CPD. More research in this area is required.

These sensory and acceptability findings, together with the observations showing no significant changes in the mean MNWS scores when subjects switched from exclusive cigarette smoking to dual use with the STPs, indicate that these products may be acceptable to smokers who wish to decrease their daily cigarette consumption rates.

In summary, results from these investigations provide an initial indication of exposure changes that may occur when smokers are switched to reduced CPD concurrent with dual use with a STP in their typical environments. Toxicant exposure under these circumstances did not statistically significantly increase, and for many toxicants, exposure significantly decreased during dual use. Biomarker changes during dual use did not reach the same magnitude as the estimated MLE changes. Because subjects were not confined to a clinic during participation, self-reporting errors of product use and urine collection were possible. Future studies that employ techniques to monitor daily diary compliance, such as electronic diaries, may improve the ability to assess the amount of dual use that occurs during ad libitum use. 


\section{ACKNOWLEDGEMENTS}

The authors gratefully acknowledge Mr. Walt Morgan and Drs. Darlene Lawson, Paul Nelson, Gerhard Scherer, and Eckhardt Schmidt for review of this manuscript. In addition, the contributions of Sheri Bowman, Alma Campbell, Kelly Harger, Tracy Hefner, Misty Mathews, and Angela Slater were essential to the execution of this work.

\section{REFERENCES}

1. Department of Health and Human Services, Food and Drug Administration: Deeming Tobacco Products to be Subject to the Federal Food, Drug, and Cosmetic Act, As Amended by the Family Smoking Prevention and Tobacco Control Act; Regulations on the Sale and Distribution of Tobacco Products and Required Warning Statements for Tobacco Products; Proposed Rules; Fed. Regist. 79 (2014) 23142-23207, available at: http://www.gpo.gov/fdsys/pkg/FR-2014-0425/pdf/2014-09491.pdf (accessed April 2015).

2. Stratton, K., P. Shetty, R. Wallace, and S. Bondurant (Editors): Clearing the Smoke: Assessing the Science Base for Tobacco Harm Reduction; National Academies Press, Washington, DC, USA, 2001.

3. Zeller, M. and D. Hatsukami: The Strategic Dialogue on Tobacco Harm Reduction: A Vision and Blueprint for Action in the US; Tob. Control 18 (2009) 324-332.

4. Foulds, J., L. Ramstrom, M. Burke, and K. Fagerström: Effect of Smokeless Tobacco (Snus) on Smoking and Public Health in Sweden; Tob. Control 12 (2003) 349-359.

5. Roth, D.H., A.B. Roth, and X. Liu: Health Risks of Smoking Compared to Swedish Snus; Inhal. Toxicol. 17 (2005) 741-748.

6. Schildt, E.B., M. Eriksson, L. Hardell, and A. Magnuson: Oral Snuff, Smoking Habits and Alcohol Consumption in Relation to Oral Cancer in a Swedish CaseControl Study; Int. J. Cancer 77 (1998) 341-346.

7. Tobacco Products Scientific Advisory Committee: Summary: TPSAC Report on Dissolvable Tobacco Products; 2012, available at: http:/www.fda.gov/ downloads/advisorycommittee/committeemeeting materials/tobaccoproductsscientificadvisorycommittee/ ucm290182.pdf (accessed April 2015).

8. Sarkar, M., J. Liu, T. Koval, J. Wang, S. Feng, R. Serafin, Y. Jin, Y. Xie, K. Newland, and H.J . Roethig: Evaluation of Biomarkers of Exposure in Adult Smokers Using Marlboro Snus; Nicotine Tob. Res. 12 (2010) 105-116.

9. Krautter, G.R. and M.F. Borgerding: Comparison of Consumption Patterns, Biomarkers of Exposure and Subjective Effects in Cigarette Smokers Switched to Dissolvable Tobacco (Camel Orbs), Dual Use, or Tobacco Abstinence; Nicotine Tob. Res. 16 (2014) 1336-1347, doi:10.1093/ntr/ntu082.

10. Krautter, G.R., P.X. Chen, and M.F. Borgerding: Consumption Patterns and Biomarkers of Exposure in Cigarette Smokers Switched to Snus, Various Dissolvable Tobacco Products, Dual Use, or Tobacco Abstinence; Regul. Toxicol. Pharmacol. 71 (2015) 186-197.
11. Health Canada: Official Method T-310 - Determination of Whole Tobacco pH; Health Canada, Ottawa, Canada, 1999.

12. AOAC: AOAC Method 966.02, Moisture in tobacco; in: Official Methods of Analysis of AOAC International, AOAC International, Gaithersburg, MD, USA, 2000, pp. 2387-2417.

13. U.S. Department of Health and Human Services, Centers for Disease Control and Prevention: Revised Protocol for Analysis of Nicotine, Total Moisture, and pH in Smokeless Tobacco Products; Federal Register, Volume 73, Number 121, p. 35396-35402, Washington, D.C., June 23, 2008, available at: http://www.gpo.gov/ fdsys/pkg/FR-2008-06-23/pdf/E8-14112.pdf

14. Wu, W., D.L. Ashley, and C.H. Watson: Simultaneous Determination of Five Tobacco-Specific Nitrosamines in Mainstream Cigarette Smoke by Isotope Dilution Liquid Chromatography/Electrospray Ionization Tandem Mass Spectrometry; Anal. Chem. 75 (2003) 4827-4832.

15. Wagner, K.A., N.H. Finkel, J.E. Fossett, and I.G. Gillman: Development of a Quantitative Method for the Analysis of Tobacco-Specific Nitrosamines in Mainstream Cigarette Smoke Using Isotope Dilution Liquid Chromatography/Electrospray Ionization Tandem Mass Spectrometry; Anal. Chem. 77 (2005) 1001-1006.

16. Wu, J., P. Joza, M. Sharifi, W.S. Rickert, and J.H. Lauterbach: Quantitative Method for the Analysis of Tobacco-Specific Nitrosamines in Cigarette Tobacco and Mainstream Cigarette Smoke by Use of Isotope Dilution Liquid Chromatography Tandem Mass Spectrometry; Anal. Chem. 80 (2008) 1341-1345.

17. AOAC: AOAC Method 973.30, Polycyclic Aromatic Hydrocarbons and Benzo $[a]$ pyrene in Food - Spectrophotometric Method; in: Official Methods of Analysis of AOAC International, AOAC International, Gaithersburg, MD, USA, 1995, pp. 1176-1178.

18. Tomkins, B.A., R.A. Jenkins, W.H. Griest, R.R. Reagan, and S.K. Holladay: Liquid Chromatographic Determination of Benzo[a]pyrene in Total Particulate Matter of Cigarette Smoke; J. Assoc. Off. Anal. Chem. 65 (1985) 935-940.

19. Gmeiner, G., G. Stehlik, and H. Tausch: Determination of Seventeen Polycyclic Aromatic Hydrocarbons in Tobacco Smoke Condensate; J. Chromatogr. A 767 (1997) 163-169.

20. Rutqvist, L.E., M. Curvall, T. Hassler, T. Ringberger, and I. Wahlberg: Swedish Snus and the GothiaTek ${ }^{\circledR}$ Standard; Harm Reduct. J. 8 (2011) 11.

21. Nelson, P.R., P. Chen, M. Dixon, and T. Steichen: A Survey of Mouth Level Exposure to Cigarette Smoke in the United States; Regul. Toxicol. Pharmacol. 61 (2011) Suppl. 3, S25-S38.

22. St Charles, F.K., M. Ashley, C.J. Shepperd, P. Clayton, and G. Errington: A Robust Method for Estimating Human Smoked Cigarette Yields From Filter Analysis Data; Beitr. Tabakforsch. Int. 23 (2009) 232-243.

23. Caraway, J.C. and P.X. Chen: Assessment of MouthLevel Exposure to Tobacco Constituents in U.S. Snus Consumers; Nicotine Tob. Res. 15 (2013) 670-677.

24. International Organization for Standardization (ISO) : ISO 3308:2000 - Routine analytical cigarette-smoking 
machine -- Definitions and standard conditions; ISO, Geneva, Switzerland, 2000.

25. Health Canada: Official Method T-111 - Determination of Nitrosamines in Mainstream Tobacco Smoke; Health Canada, Ottawa, Canada, 1999.

26. Health Canada: Official Method T-115-Determination of "Tar", Nicotine and Carbon Monoxide in Mainstream Tobacco Smoke; Health Canada, Ottawa, Canada, 1999.

27. Meger, M., I. Meger-Kossien, A. Schuler-Metz, D. Janket, and G. Scherer: Simultaneous Determination of Nicotine and Eight Nicotine Metabolites in Urine of Smokers Using Liquid Chromatography-Tandem Mass Spectrometry; J. Chromatogr. B 778 (2002) 251-261.

28. Wu, A.H.B. (Editor): Tietz Clinical Guide to Laboratory Tests, $4^{\text {th }}$ Edition; W.B. Saunders Company, St. Louis, MO, USA, 2006.

29. Kavvadias, D., G. Scherer, M. Urban, F. Cheung, G. Errington, J. Shepperd, and M. McEwan: Simultaneous Determination of Four Tobacco-specific $N$-nitrosamines (TSNA) in Human Urine; J. Chromatogr. B 877 (2009) 1185-1192.

30. Urban, M., D. Kavvadias, K. Riedel, G. Scherer, and A.R. Tricker: Urinary Mercapturic Acids and a Haemoglobin Adduct for the Dosimetry of Acrylamide Exposure in Smokers and Nonsmokers; Inhal. Toxicol. 18 (2006) 831-839.

31. Riedel, K., G. Scherer, J. Engl, H.-W. Hagedorn, and A.R. Tricker: Determination of Three Carcinogenic Aromatic Amines in Urine of Smokers and Nonsmokers; J. Anal. Toxicol. 30 (2006) 187-195.

32. Ramsauer, B., K. Sterz, H.-W. Hagedorn, J. Engl, G. Scherer, M. McEwan, G. Errington, J. Shepperd, and F. Cheung: A Liquid Chromatography/Tandem Mass Spectrometry (LC-MS/MS) Method for the Determination of Phenolic Polycyclic Aromatic Hydrocarbons (OH-PAH) in Urine of Non-Smokers and Smokers; Anal. Bioanal. Chem. 399 (2011) 877-889.

33. Paci, E., D. Pigini, A.M. Cialdella, P. Faranda, and G. Tranfo: Determination of Free and Total $S$-phenylmercapturic Acid by HPLC/MS/MS in the Biological Monitoring of Benzene Exposure; Biomarkers 12 (2007) 111-122.

34. Sterz, K., D. Köhler, T. Schettgen, and G. Scherer: Enrichment and Properties of Urinary pre- $S$ Phenylmercapturic Acid (pre-SPMA); J. Chromatogr. B 878 (2010) 2502-2505.

35. Scherer, G., M. Urban, H.-W. Hagedorn, S. Feng, R.D. Kinser, M. Sarkar, Q. Liang, and H.-J. Roethig: Determination of Two Mercapturic Acids Related to Crotonaldehyde in Human Urine: Influence of Smoking; Hum. Exp. Toxicol. 26 (2007) 37-47.

36. Urban, M., G. Gilch, G. Schepers, E. van Miert, and G. Scherer: Determination of the Major Mercapturic Acids of 1,3-Butadiene in Human and Rat Urine Using Liquid Chromatography with Tandem Mass Spectrometry; J. Chromatogr. B 796 (2003) 131-140.

37. Scherer, G., M. Urban, H.-W. Hagedorn, R. Serafin, S. Feng, S. Kapur, R. Muhammad, Y. Jin, M. Sarkar, and H.-J. Roethig: Determination of Methyl-, 2-Hydroxyethyl-, and 2-Cyanoethylmercapturic Acids as Biomarkers of Exposure to Alkylating Agents in Cigarette
Smoke; J. Chromatogr. B 878 (2010) 2520-2528.

38. Toraño, J.S. and H.J. van Kan: Simultaneous Determination of the Tobacco Smoke Uptake Parameters Nicotine, Cotinine and Thiocyanate in Urine, Saliva and Hair, Using Gas Chromatography-Mass Spectrometry for Characterisation of Smoking Status of Recently Exposed Subjects; Analyst 128 (2003) 838-843.

39. Hughes, J.R. and D. Hatsukami: Signs and Symptoms of Tobacco Withdrawal; Arch. Gen. Psychiatry 43 (1986) 289-294.

40. Hughes, J.R: Effect of Abstinence From Tobacco: Valid Symptoms and Time Course; Nicotine Tob. Res. 9 (2007) 315-327.

41. American Psychiatric Association: Diagnostic and Statistical Manual of Mental Disorders, $4^{\text {th }}$ Edition; American Psychiatric Association, Washington, DC, USA, 2000.

42. Benowitz, N.L., P. Jacob III, L.T. Kozlowski, and L. $\mathrm{Yu}$ : Influence of Smoking Fewer Cigarettes on Exposure to Tar, Nicotine, and Carbon Monoxide; N. Engl. J. Med. 315 (1986) 1310-1313.

43. Fagerström, K.O. and J.R. Hughes: Nicotine Concentrations with Concurrent Use of Cigarettes and Nicotine Replacement: A Review; Nicotine Tob. Res. 4 Suppl. 2 (2002) S73-S79.

44. Hecht, S.S., S.E. Murphy, S.G. Carmella, C.L. Zimmerman, L. Losey, I. Kramarczuk, M.R. Roe, S.S. Puumala, Y.S. Li, C. Le, J. Jensen, and D.K. Hatsukami: Effects of Reduced Cigarette Smoking on the Uptake of a Tobacco-Specific Lung Carcinogen; J. Natl. Cancer Inst. 96 (2004) 107-115.

45. Hecht, S.S., S.G. Carmella, K.-A. Le, S.E. Murphy, Y.S. Li, C. Le, J. Jensen, and D.K. Hatsukami: Effects of Reduced Cigarette Smoking on Levels of 1-Hydroxypyrene in Urine; Cancer Epidemiol. Biomarkers Prev. 13 (2004) 834-842.

46. Hurt, R.D., G.A. Croghan, T.D. Wolter, I.T. Croghan, K.P. Offord, G.M. Williams, M.V. Djordjevic, J.P. Richie, and A.M. Jeffrey: Does Smoking Reduction Result in Reduction of Biomarkers Associated with Harm? A Pilot Study Using a Nicotine Inhaler; Nicotine Tob. Res. 2 (2000) 327-336.

47. Theophilus E.H., C.R.E. Coggins, P. Chen, E. Schmidt, and M.F. Borgerding: Magnitudes of Biomarker Reductions in Response to Controlled Reductions in Cigarettes Smoked Per Day: A One-Week Clinical Confinement Study; Regul. Toxicol. Pharmacol. 71 (2015) 225-234.

48. Armitage, A.K., M. Dixon, B.E. Frost, D.C. Mariner, and N.M. Sinclair: The Effect of Inhalation Volume and Breath-hold on the Retention of Nicotine and Solanesol in the Human Respiratory Tract and on Subsequent Plasma Nicotine Concentration During Cigarette Smoking; Beitr. Tabakforsch. Int. 21 (2004) 240-249.

49. Feng, S., S.E. Plunkett, K. Lam, S. Kapur, R. Muhammad, Y. Jin, M. Zimmermann, P. Mendes, R. Kinser, and H.J. Roethig: A New Method for Estimating the Retention of Selected Smoke Constituents in the Respiratory Tract of Smokers During Cigarette Smoking; Inhal. Toxicol. 19 (2007) 169-179.

50. Moldoveanu, S., W. Coleman III, and J. Wilkins: Determination of Carbonyl Compounds in Exhaled Cigarette 
Smoke; Beitr. Tabakforsch. Int. 22 (2007) 346-357.

51. Moldoveanu, S., W. Coleman III, and J. Wilkins: Determination of Benzene and Toluene in Exhaled Cigarette Smoke; Beitr. Tabakforsch. Int. 23 (2008) 107-114.

52. Stone, A.A., S. Shiffman, J.E. Schwartz, J.E. Broderick, and M.R. Hufford: Patient Compliance with Paper and Electronic Diaries; Control. Clin. Trials 24 (2003) 182-199.

53. Broderick, J.E., J.E. Schwartz, S. Shiffman, M.R. Hufford, and A.A. Stone: Signaling Does Not Adequately Improve Diary Compliance; Ann. Behav. Med. 26 (2003) 139-148.

54. Hecht, S.S., S.G. Carmella, M. Chen, J.F. Dor Koch, A.T. Miller, S.E. Murphy, J.A. Jensen, C.L. Zimmerman, and D.K. Hatsukami: Quantitation of Urinary Metabolites of a Tobacco-Specific Lung Carcinogen After Smoking Cessation; Cancer Res. 59 (1999) 590-596.

55. Hecht, S.S., S.G. Carmella, M. Ye, K.-A. Le, J.A. Jensen, C.L. Zimmerman, and D.K. Hatsukami: Quantitation of Metabolites of 4-(Methylnitrosamino)-1-(3pyridyl)-1-butanone after Cessation of Smokeless Tobacco Use; Cancer Res. 62 (2002) 129-134.
56. Goniewicz, M.L., C.M. Havel, M.W. Peng, P. Jacob III, D. Dempsey, L. Yu, W. Zielinska-Danch, B. Koszowski, J. Czogala, A. Sobczak, and N.L. Benowitz: Elimination Kinetics of the Tobacco-Specific Biomarker and Lung Carcinogen 4-(Methylnitrosamino)-1(3-pyridyl)-1-butanol; Cancer Epidemiol. Biomarkers Prev. 18 (2009) 3421-3425.

Corresponding author:

Elaine Round

Research and Development

R.J. Reynolds Tobacco Company

P.O. Box 1487

Winston-Salem, NC 27102

USA

Email: rounde@rjrt.com 